Article

\title{
Sustaining Language Skills Development of Pre-Service EFL Teachers despite the COVID-19 Interruption: A Case of Emergency Distance Education ${ }^{\dagger}$
}

\author{
Tuçe Öztürk Karataş ${ }^{1}$ and Hülya Tuncer ${ }^{2, *}$ \\ 1 English Language Teaching Department, Faculty of Education, Mersin University, Mersin 33343, Turkey; \\ tozturkkaratas@mersin.edu.tr \\ 2 English Language Teaching Department, Faculty of Education, Çukurova University, Adana 01330, Turkey \\ * Correspondence: hulyatan@cu.edu.tr; Tel.: +90-322-3386084 (ext. 2793-23) \\ + A preliminary version of this study was presented at the 6th International Conference on Lifelong Education \\ and Leadership for All, ICLEL 2020, July 16-18, 2020, Sakarya University, Turkey.
}

Received: 29 August 2020; Accepted: 1 October 2020; Published: 4 October 2020

\begin{abstract}
The COVID-19 pandemic has caused teachers and students to abandon their physical classrooms and move into emergency distance education (EDE) settings. Thus, sustaining the quality in education has become a challenge during this transitional period. Within this context, the aim of this study was to explore the impact of EDE on language skills development (reading, writing, listening, and speaking) of Turkish pre-service teachers of English as a foreign language (EFL). In this qualitative study, data were gathered from 118 pre-service EFL teachers about the advantages and disadvantages of EDE for their language skills development. Thematic analysis was used as a research design, and nine themes emerged for both advantages and disadvantages. The most important theme for both categories is content and implementation of online courses. This study pinpointed the eminence of this theme, for if it is emphasized enough and handled efficiently, it plays a huge role in developing language skills. The themes and sub-themes generated through thematic analysis showed the advantages and disadvantages of EDE for each skill in detail and also proved that EDE was most advantageous for writing skill and least advantageous for speaking skill. The participants stated that, since writing skill was constantly used for almost all homework, assignments and projects, that skill was nurtured the most. Nevertheless, speaking skill was ignored during online courses, and writing became the new mode of communication by replacing speaking. The outcome of the present study encourages preparedness for EDE against a possible second wave. Thus, the study is hoped to pave the way for anticipating issues and developing solutions for EDE contexts to preserve sustainability in higher education.
\end{abstract}

Keywords: COVID-19; emergency distance education (EDE); English language skills; pre-service teachers; English as a Foreign Language (EFL)

\section{Introduction}

COVID-19 is a health crisis that has affected and changed our habits and common elements of our life. In the digital age, the spread of COVID-19 is the first crisis with such global effects [1]. Across the globe, education has non-immunity [2], and in the related literature, the pre-COVID world has been defined with these words: “Up until very recently, worldwide higher education has lived a dream of prosperous global exchange and sustainable development ... The COVID-19 pandemic has brought about enormous hindrance to the internationalization of higher education in our increasingly globalized, yet divided, world" [3] (p. 2). Indeed, COVID-19, announced as 
a pandemic by the World Health Organization on 11 March 2020 [4], rapidly became a massive international concern. The COVID-19 crisis has affected all spheres of life. In fact, the pandemic has endangered the achievement of UN Sustainable Development Goals (SDGs) set to improve people's lives and the natural world by 2030 [5].

It is accepted worldwide that one of the best public policy tools for teaching and learning is to go to school. However, with COVID-19, many countries have closed schools, colleges, and universities in order to save lives by reducing physical contact. Schooling at all stages has had to adapt learning, teaching, and assessment practices to quickly changing circumstances. This crisis immediately moved these practices to uncertainty for everyone. All on-going activities were immediately cancelled. The closure of schools, colleges, and universities has shifted teaching and assessment around the world to online platforms. This immediate and new world has been a massive shock for students, teachers, and families. According to a recent report by United Nations Educational, Scientific and Cultural Organization (UNESCO) [6], currently, $1,575,270,054$ learners are excluded from the normal learning process. Indeed, the COVID-19 pandemic has become a major threat for the implementation of UN Sustainable Development Goal 4 (SDG 4) $[5,7,8]$ which is to "ensure inclusive and equitable quality education and promote lifelong learning opportunities for all" [9]. With the circumstances of the COVID-19 interruption, urgent actions are needed to achieve the objectives of SDG 4 [7]. It is because of the fact that the global lockdown of schools and universities is going to cause major short and long-term consequences for institutions and individuals in terms of learning, teaching and assessment. On the positive side, while the spread of the virus has far-reaching consequences, the closure of schools has led to innovative methods of delivering education ensuring the continuity of studying by learners [10], proving that "Even though schools have closed, learning has not ended" [11] (p. 129).

In order to overcome the COVID-19 disruption to education (SDG 4-Quality Education), the immediate response is "to turn to distance and online learning" [12]. In fact, various opportunities have been introduced to the field of education so as to continue education practices during emergency circumstances and maximize online platforms [13]. Considering higher education in particular, higher education institutions were forced by the COVID-19 pandemic to sustain education through online facilities instead of traditional face-to-face education in physical classrooms $[14,15]$. Thus, many universities rescheduled their academic calendars and started to utilize various methods to enable the continuity of the curricula through virtual campuses, the media, or other digital environments. This action was necessary to promote undisrupted learning at this critical moment and prevent the expansion of COVID-19 on university campuses [6].

In the pre-COVID-19 world, "the expansion of e-learning products is one of the fastest growing areas of education" [16] (p. 1865). Online education opportunities were so much popular because they provided the effective and flexible contexts facilitating mutual interaction by eliminating time and location problems [17]. Those online practices including high-quality online education procedures or courses are titled by different terminologies such as "distance education," "e-learning," "virtual learning and teaching," or "online learning and teaching." All of them meet on the common ground that all "refer to the method of content dissemination and rapid learning through the application of information technology and Internet technology" [18] (p. 502). In such circumstances, learners are defined as distance learners who are "students using on-line, Web-based instruction at a distance from the main campus" [19] (p. 44). In fact, in addition to removing temporal and geographical hindrances, those online education procedures have flexible, adaptive, and individualized natures while fostering autonomous learning [20]. Indeed, the practices and procedures of distance education, remote teaching, and online instruction are not new and vague for pedagogy. However, learning and teaching procedures "have taken on renewed salience" due to the pandemic [21] (p. 108). It must be understood that "well-planned online learning experiences are meaningfully different from courses offered online in response to a crisis or disaster. Colleges and universities working to maintain instruction during the COVID-19 pandemic should understand those differences when evaluating this emergency remote teaching" [22] (p. 1). Alternative terms such as emergency remote teaching 
(ERT), emergency eLearning, or emergency distance education (EDE) are used by researchers for the new online learning and teaching, with the purpose of drawing attention to the difference between online education during the pandemic and high-quality online education before the pandemic [1,20,22-24]. Emergency remote teaching (ERT) refers to the "temporary shift of instructional delivery to an alternate delivery mode due to crisis circumstances" [22] (p. 6). Its main purpose is to provide temporary support for the continuity of education [20]. That is why "online education" differs from "emergency online education" or "emergency distance education."

Thus, this transition might result in many challenges that teachers and students at all stages of schooling come across. It is because "teachers are not immune to the vulnerabilities due to Covid-19" [13] (p. 22). In fact, hurrying to move education online in these emergency circumstances might create difficulties in taking advantage of this virtual learning and teaching procedure. Quality education (SDG 4) that "never means education in the classroom" but refers to "the teaching learning process aimed to live and lead a life as a good citizen" [25] (p. 8) can be more uneven. All students may not have internet access, computers, and a suitable learning environment to handle the activities assigned through online education platforms. Such inequalities might threaten the objectives of SDG $4[7,8]$. Additionally, "the design process and the careful consideration of different design decisions have an impact on the quality of the instruction. And it is this careful design process that will be absent in most cases in these emergency shifts" [22] (p. 3). The quality of a course depends on a proper design and can take a long time to achieve; yet, due to the pandemic, a rapid approach for course implementation and delivery has been adopted. At this point, applications and implementation have taken many and diverse forms in EDE [23], and today, much research has been devoted to exploring this new learning environment, including ELT departments. The objectives of ELT departments in Turkey can be considered similar. An example statement of two state universities might clarify those objectives better: "[ $\mathrm{t}]$ he objective of the program is to help students to achieve mastery of the English Language and thus provide them with the knowledge and practical skills for teaching English as a foreign language" $[26,27]$. In accordance with the departmental objectives, curriculum of ELT departments specified by the Higher Education Council (YÖK) of Turkey includes skill-based courses to help students to achieve mastery of the English Language. The courses for developing those skills are (first year) Reading Skills I and II, Writing Skills I and II, Listening and Pronunciation I and II, and Oral Communication Skills I and II and (second year) Critical Reading and Writing. The courses for teaching the skills are (third year) Teaching Language Skills I and II. In addition, some of the elective courses also focus on development of and teaching the four language skills [28].

Knowledge base is defined as "the expertise, understanding, awareness, knowledge, and skills that second-language teachers need to possess in order to be effective teachers" [29] (p. 32). Richards [30] proposes six dimensions for core knowledge base of second language teachers: theories of teaching, teaching skills, communication skills and language proficiency, subject matter knowledge, pedagogical reasoning and decision making, and contextual knowledge. It is within the third dimension (communication skills and language proficiency) that four language skills are included. Some scholars in the field [31,32] pinpoint the importance of communicative competence for L2 teaching. Uso-Juan and Martinez-Flor [33] put forward a framework for communicative competence by placing discourse competence at the center where all four language skills are embodied. Based upon these premises, there have been numerous studies focusing on skills development for non-native teachers-for instance, the ones concluding that non-native teachers of English feel incompetent about the language proficiency dimension $[34,35]$. There are studies within the Turkish context focusing on those feelings as well [36] - specifically on speaking skills $[37,38]$ and on the need for more courses for linguistic competence of pre-service EFL teachers [39].

The four language skills (reading, writing, listening, and speaking) are the heart of a language (L2) class. Regarding language education before COVID-19, it was common to realize some tasks or activities involving and integrating more than just one language skill. Certainly, however, it was very possible to see moments in which learners were engaged with a single language skill, especially during 
the courses in language teacher training programs. The most likely scene was that of a class in which skills were integrated as in actual language use and rarely in isolation. Now, in the COVID-19 world, under the new emergency circumstances, the purpose of online language education should be "to provide and facilitate access to a multilingual community, which offers opportunities for sufficient input, output, and interaction in multiple modalities and settings with feedback from peers, the teacher, and technology with the possibility for individualization" [20] (p. 382). However, English language teaching varies in implementation and adaptation. Therefore, some new realities have started to emerge due to the COVID-19 pandemic's profound effects.

Though the use of online tools and practices is not something new for most language instructors and students, it is challenging [40]. For EDE, what is expected for future practices is not only sharing tools and materials for learners but dealing with learners' needs and learning contexts. The main difference between distance education and EDE is about the way learners are engaged in the process. This difference is best stated with the following: "while distance education has always been an alternative and flexible option for learners, emergency remote teaching is an obligation, which means that we have to use different strategies and approach the case with different priorities" [1] (p. ii).

Even in the pre-COVID world, where most of the online education activities were optional, the studies evaluating online programs were too few [41]. When the unsustainable educational context due to COVID-19 is considered, it becomes more urgent to evaluate the online activities conducted during this emergency pandemic process in case of a second wave. In order to be more innovative and effective about providing learning opportunities in the virtual environment, it becomes more crucial to deal with "the need of assessing the effectiveness of online educational opportunities" [17] (p. 118). In these unprecedented circumstances, what is important is not only content and knowledge of teaching and learning but also the medium utilized by teachers and educators [42]. Attempting quickly to implement EDE, little research attention has been considered in documenting and analyzing those attempts [43]. Additionally, the impact of EDE on the language teacher training context has not yet been fully understood. What is missing is an overview of the positive and negative aspects of EDE activities focusing on self-perception and evaluation of online activities by various stakeholders, especially students. Although some studies dealt with understanding the participants' perspective [16,44-46], the lack of research on that was stated in the studies conducted before the COVID-19 pandemic by several authors [16,45-47]. At this point, a wider research perspective is needed to address this gap: the perspective of the students as the emergency distance learners [48].

In the reviewed literature, online learning experiences in the pre-COVID educational context are meaningfully diverse from the virtual experiences and courses sustaining instruction in response to the COVID-19 interruption. The different nature of this emergency-remote teaching and learning-should be taken into consideration while evaluating EDE practices [22]. Thus, the stakeholders-students, academic and administrative staffs-have been affected by urgent migration to EDE. Considering that EDE is a viable option for the continuity of education and learning in the current unsustainable circumstance that COVID-19 has caused, the question arises, "Does it work?" To this end, this study is driven by the crucial and decisive role of education "in directing societies towards changes that will result in a sustainable future" [49] (p. 2). In order to create an attempt to implement quality education (SDG 4) in the pandemic context, this study specifically aims to understand how the COVID-19 interruption has affected the development of language skills of pre-service EFL teachers. It focuses on clarifying the actual personal experiences and voices of Turkish pre-service EFL teachers on language skills development during this EDE process, which is accepted as an important facet of quality assessment and sustainability [50]. Thus, aiming to reduce the frangibility of SDG 4 during the COVID-19 pandemic, this study provides windows to pre-service EFL teachers by examining the advantages and disadvantages of EDE brought by the COVID-19 pandemic for sustaining the development of their language skills (reading, writing, listening, and speaking). 


\section{Materials and Methods}

\subsection{Research Context}

In Turkey, there are nearly eight million students and more than 170 thousand $(174,494)$ teaching staff in higher education [51]. When the localized transmission of COVID-19 virus was recorded on 10 March 2020, the Turkish government regarded it as a risk to national security and later implemented quarantine in areas where there were COVID-19 cases due to a spike in newly confirmed patients and local transmission. The Ministry of National Education (MoNE) of Turkey began carrying out online education on 23 March 2020 [52]. On the same day, universities in Turkey also started to run online courses through virtual platforms in order to prevent the increasing spread of COVID-19 and to maintain the health of students, teachers, and all educational staff [53]. Hence, students began to study and learn at home, and teachers worked from home. Face-to-face education in the classroom setting turned into online learning and distance education until the end of the semester. This abrupt shift from face-to-face education to online education was COVID-19 crisis-driven. This new online education procedure was conducted in emergency circumstances of the first wave of the pandemic. Thus, this EDE process brought new challenges for both students and teachers to sustain learning and teaching. Moreover, all assessment and testing practices conducted at universities in Turkey were moved to online platforms in accordance with the decision of YÖK. Midterm, final, and make-up exams were mostly evaluated through assignments and projects $[48,54]$. The move of the universities in Turkey to distance education modes or platforms did not affect each of those universities to the same degree: some were already conducting online courses, some did not have any experience of it, some were preparing, some tried to do their best in transforming, and so forth. However, the most common practice during EDE was adopting an online platform where students can log in and access virtual classrooms corresponding to the physical classes in the campus. When they click on the relevant course, they can see and follow the instructions of the lecturers synchronously and asynchronously. In addition, they can access the training videos and user manual about the use of the distance education platform, which provided flexibility for students.

Within this context, teachers in ELT departments tried to adapt to the new normal and struggled to move their pedagogical practices to online environments, and they conducted their lessons either synchronously or asynchronously, or sometimes both. The two authors experienced similar things as well. Having no previous online teaching experience, they tried to implement their lessons through as many channels as possible to sustain student learning in addition to the platform of their universities. Since no single language teaching methodology was seen as comprehensive and flexible enough to fulfil the needs of learners during EDE, they conducted their courses as student-centered as possible: highlighting the importance of interaction, cooperation and collaboration for both student to teacher and student to student. However, these interactions were limited in the case of these two researchers and for most of the universities because participation was not obligatory, so the students could only watch the lesson recordings as well.

On 15 June 2020, the academic calendars of the universities in Turkey were updated. The higher education institutions then recalibrated and started to continue their cancelled plans, actions, and activities in accordance with their own circumstances [55]. For the time being, the future of higher education institutions for the academic year 2020-2021 maintains its uncertainty with variety of alternatives including face to face, online, and hybrid solutions, although most of the universities have decided to conduct online courses.

\subsection{Research Questions}

The idea for this study was generated by what the authors experienced during EDE. One of the authors was delivering Oral Communication Skills courses before the COVID-19 pandemic, and after the outbreak of the virus, she experienced difficulties in transforming the course to online platforms both in terms of the content and assessment techniques. The other author was also going 
through problems with her students' oral participation to her classes during EDE. Since EDE was a new process for both authors, they felt that skills development of their students, especially for speaking, was falling behind, and they decided to search for students' perspective about the development of each skill in detail in order to compare and contrast them. The studies within the related field presented some supporting outcomes and also demonstrated the scarcity of such studies for EDE contexts. Thus, being aware of the current unsustainable circumstances that COVID-19 has caused in education, this study focused on the impact of emergency distance education (EDE, the preferred terminology in this study) on sustaining language skills development for Turkish pre-service EFL teachers. With this aim in mind, the study tried to find answers to the following research questions:

1. What are the advantages of emergency distance education on sustaining the language skills (reading, writing, listening, and speaking) development of pre-service EFL teachers?

2. What are the disadvantages of emergency distance education on sustaining the language skills (reading, writing, listening, and speaking) development of pre-service EFL teachers?

3. Which language skill (reading, writing, listening, or speaking) is most positively affected by the emergency distance education for pre-service EFL teachers?

4. Which language skill (reading, writing, listening, or speaking) is most negatively affected by the emergency distance education for pre-service EFL teachers?

\subsection{Method}

The present study is a qualitative descriptive research based on thematic analysis (TA). TA is a descriptive method of "identifying, analysing, and reporting patterns (themes) within data" [56] (p. 6). The primary aim of using TA in this study is to gain a richer, deeper understanding of the impact of EDE on sustaining language skills development of pre-service EFL teachers by eliciting the experiences of those directly affected by EDE. To do so, some themes and sub-themes capturing crucial labels in relation to each research question were determined. In this study, themes represented "some level of patterned response or meaning within the data set" [56] (p. 10). Both themes and sub-themes generated through TA provided a rich thematic description and reflection of the content of the answer for each research question of this study.

\subsection{Participants}

In this study, convenience sampling was used. The researchers asked their own students in the ELT departments of their universities to participate in the study. These students from two different state universities constituted more than half of the participants $(63 \%)$. To gather as much information as possible, close colleagues working at ELT departments of the other state universities in Turkey were asked to distribute the questionnaire to their students. Because of the pandemic crisis, the researchers collected the responses through an online Google Forms questionnaire instead of in person. In total, 118 Turkish pre-service EFL teachers consisting of 80 females $(68 \%)$ and 38 males (32\%) from eight different state universities in Turkey participated in the study. The first-, second-, third-, and fourth-year students constituted $28 \%, 27 \%, 22 \%$, and $22 \%$ of the participants, respectively. In total, these students, whose ages varied mostly from 18 to 24 years, constituted most of the participants $(87 \%)$. All participants gave their informed consent for inclusion before they took part in the study, and the researchers ensured their anonymity at all stages of the study. The study also received its approval from the Ethics Committee of Çukurova University (09/09/2020-E.107086).

\subsection{Data Collection Tool}

A questionnaire including open-ended questions (see Appendix A) was employed to collect data at the end of the spring term of the academic year 2019-2020. The questionnaire focused on the impact of COVID-19 on English language skills development. The first draft was administered to five non-participant pre-service EFL teachers. In accordance with the piloting outcomes, the researchers 
made the necessary changes and prepared the final form of the questionnaire. While filling out the questionnaire, the participants were free to use English or Turkish. However, nearly all of the participants preferred to present their answers in English.

\subsection{Data Analysis}

As stated above, TA formed the backbone of this study. The data for TA were gathered from open-ended responses from the questionnaire. TA was carried out by two researchers. In order to reduce the data into workable themes and subthemes related to each research question, this study followed six phases based on Braun and Clarke's [56] methodology for TA:

- Phase 1: familiarization with data;

- Phase 2: generating initial codes;

- Phase 3: searching for themes;

- Phase 4: reviewing themes;

- Phase 5: defining and naming themes;

- Phase 6: producing the report.

Prior to conducting TA, the participants were numbered, and the raw data of answers for each research question were compiled in a separate word file. Then, each researcher read and reread the data for each research question individually to become familiarized with the nature of the data. After they became familiar with the depth and breadth of all aspects of the content of the data, each researcher individually took notes to document initial lists of thoughts and ideas for coding of the first half of the data. They then discussed their notes and ideas for codes and decided on the route together before completing the whole analysis. In the second phase, they began the coding process together. Driven with the questions in mind, through the semantic and conceptual reading of the relevant data extracts, the researchers produced initial codes for each question by manually organizing the raw data into meaningful groups and labels. If the same subject matter was labelled with a different code, the most appropriate code was chosen. At end of this phase, the researchers had a long list of various codes for each question and each skill. In the third phase, they first stated the codes and the possible themes overarching those codes. After careful and detailed review of all extracts, they analyzed the relevant coded data extracts and sorted the codes into potential themes together. For some themes and sub-themes on which they disagreed, the discussion ended with a consensus. The researchers ended this phase by drawing a table sorting the different codes into themes and sub-themes for each question with the determined extracts. In the fourth phase, the researchers reviewed and defined the themes and sub-themes. They worked on each initial theme and sub-theme again by considering whether there were any problems with each theme or sub-theme or whether they fit with the data extracts. For problematic cases, the researchers reworked on that theme by creating a new theme or by reorganizing the extracts that did not fit into the existing themes or sub-themes. In the fifth phase, another round of analysis of each theme and sub-theme was performed. The researchers identified and named each theme and sub-theme making sure it was clear what each theme or sub-theme was about. In naming the themes, the researchers benefitted from the related literature as well. For instance, although the researchers named one of the themes for disadvantages as "technical problems" first, they then changed it into "technical issues," since this terminology was used more frequently in the studies focusing on distance education. Using same or similar themes was thought to pave the way for a better comparison among the related studies. At the end of this phase, the researchers determined the frequency and percentage of codes related to each theme. In the sixth and last phase, in addition to the conclusions drawn from the data presented as themes and sub-themes, the researchers wrote up the conceptualization of this TA process in relation to existent literature on EDE for each research question. SPSS was utilized in the TA process for the calculation of the descriptive statistical information. During the TA process, inter-coder reliability was calculated as 0.95 [57], which indicated a high agreement between the coders. 
This six-phase procedure was repeated 10 times: four times for the first research question (advantages of EDE for reading, writing, listening, and speaking), four times for the second research question (disadvantages of EDE for reading, writing, listening, and speaking), once for the third question (the most positively affected skill), and once for the fourth research question (the most negatively affected skill).

\section{Results}

The results of this study address the advantages and disadvantages of EDE for sustaining language skills development of pre-service EFL teachers and the skills which are most positively and most negatively affected. Based on the research questions, four patterns emerged from TA: (1) the advantages of EDE for the language skills development of pre-service EFL teachers, (2) the disadvantages of EDE for the language skills development of pre-service EFL teachers, (3) the most positively affected skill by EDE, and (4) the most negatively affected skill by EDE. The answers for each question were diverse in both semantic richness and length, and the patterns are presented through themes and sub-themes. Each theme is clearly linked to the patterns associated with one research question. Themes and sub-themes related to each pattern were often interconnected due to participants' answers for each question being rich. The same extracts included more than one code and were categorized under various themes. The qualitative data gathered about each pattern were analyzed through thematic analysis, and the themes, sub-themes, and the descriptive statistical information related to them were demonstrated within the following sections and tables.

\subsection{The Advantages of EDE for the Language Skills Development of Pre-Service EFL Teachers}

The first question of the questionnaire asked pre-service EFL teachers about the advantageous aspects of EDE for the development of each skill. Underneath of each skill in the online questionnaire, enough space was provided so that the participants could write the positive sides in detail. The thematic analysis of all the written responses related to advantages of EDE on sustaining language skills development of pre-service EFL teachers resulted in nine main themes clarifying the causes of this pattern: content and implementation of online courses, comfortable atmosphere of home, free time, properties of distance education platform, use of computers/online tools/resources, time and cost efficiency, teacher's role, no advantages and no answer. Additionally, in total, there are 15 sub-themes across the nine themes. Indeed, the participants' responses suggest the advantages of EDE on the development of each skill (reading, writing, listening, and speaking) separately, though the themes and sub-themes are the same. Table 1 summarizes the themes, sub-themes, the frequencies and percentages of themes associated with each skill separately.

Table 1 demonstrates that the participants offered the advantageous aspects of EDE through a total of 142 comments for reading, 140 for writing, 151 for listening and 130 for speaking. According to the extracts of the participants, the content and implementation of online courses, comfortable atmosphere of home, and free time themes are the three main causes of the development of reading and writing skills, while in addition to the first theme in Table 1, the theme properties of distance education platform $(22 \%)$ is identified as the primary cause of advantages for the development of listening skill. Additionally, considering the frequency of themes related to the development of speaking skill of the pre-service EFL teachers during EDE, it is important to note that nearly half of them identified the theme of no advantages (45\%). However, some of the extracts show that during the EDE process, the themes content and implementation of online courses $(24 \%)$ and comfortable atmosphere of home $(18 \%)$ capture the reasons for the development of pre-service EFL teachers' speaking skill. 
Table 1. Summary of thematic analysis (TA) for the advantages of emergency distance education (EDE) for sustaining the development of reading, writing, listening and speaking skills.

\begin{tabular}{|c|c|c|c|c|c|c|c|c|c|c|}
\hline \multirow{2}{*}{\multicolumn{2}{|c|}{ Themes }} & \multirow{2}{*}{ Sub-Themes } & \multicolumn{2}{|c|}{ Reading } & \multicolumn{2}{|c|}{ Writing } & \multicolumn{2}{|c|}{ Listening } & \multicolumn{2}{|c|}{ Speaking } \\
\hline & & & $\mathrm{f}^{1}$ & $\%$ & f & $\%$ & $\mathrm{f}$ & $\%$ & $\mathrm{f}$ & $\%$ \\
\hline 1 & $\begin{array}{l}\text { Content and implementation of } \\
\text { online courses }\end{array}$ & $\begin{array}{l}\text { Content and amount of homework; nature of } \\
\text { midterm and final exams, more legible } \\
\text { reading materials }\end{array}$ & 45 & 32 & 55 & 40 & 32 & 21 & 31 & 24 \\
\hline 2 & Comfortable atmosphere of home & $\begin{array}{l}\text { Stress-free; autonomous learning; enthusiasm } \\
\text { and willingness for learning; motivation }\end{array}$ & 21 & 15 & 19 & 14 & 16 & 11 & 24 & 18 \\
\hline 3 & Free time & Time for more skills practice & 31 & 22 & 21 & 15 & 16 & 11 & 7 & 5 \\
\hline 4 & $\begin{array}{l}\text { Properties of distance education } \\
\text { platform }\end{array}$ & $\begin{array}{c}\text { Time and place free nature of materials } \\
\text { and online lessons; repeated watching availability } \\
\text { of online lessons }\end{array}$ & 3 & 2 & 6 & 4 & 33 & 22 & - & - \\
\hline 5 & $\begin{array}{l}\text { Use of computer/online } \\
\text { tools/resources }\end{array}$ & $\begin{array}{l}\text { Wide variety of resources on the internet; } \\
\text { use of online tools (dictionaries, etc.) }\end{array}$ & 12 & 8 & 13 & 9 & 22 & 15 & 4 & 3 \\
\hline 6 & Time and cost efficiency & Saving time and money; use of a keyboard & 8 & 6 & 5 & 4 & 1 & 1 & 2 & 2 \\
\hline 7 & Teacher's role & Feedback & - & - & 2 & 1 & - & - & - & - \\
\hline 8 & No advantages & & 17 & 12 & 16 & 11 & 24 & 16 & 58 & 45 \\
\hline 9 & No answer & & 5 & 4 & 3 & 2 & 7 & 5 & 4 & 3 \\
\hline \multicolumn{2}{|c|}{$\begin{array}{l}\text { TOTAL (frequencies are more than } 118 \\
\text { since some responses of the participants } \\
\text { included more than one theme) }\end{array}$} & & 142 & 101 & 140 & 100 & 151 & 102 & 130 & 100 \\
\hline
\end{tabular}

Focusing on the responses of the participants for the first research question, the first theme generated by TA is the content and implementation of online courses. As part of the advantages of EDE for language skills development, this theme described the positive impact of what was included in the course and how the courses were implemented during the EDE procedure. The content and implementation of online courses was thus said to be a way of developing four skills: reading $(32 \%)$, writing $(40 \%)$, listening (21\%), and speaking (24\%). This theme is described with three sub-themes: (a) content and amount of homework, (b) nature of midterm and final exams, and (c) more legible reading materials. The first sub-theme is highly associated with what was expected from the pre-service EFL teachers to do as homework and assignment and how they were expected to handle them in order to be successful in the EDE process. The following statements of the participants exemplify the sub-theme content and amount of homework better (one statement may belong to more than one theme or sub-theme, but the dominant theme or sub-theme is given here):

Participant 38 (P38): Most of our exams were assignments, and we were expected to understand assignments properly [for reading skills].

P57: Thanks to much homework (essays, movie reviews, paragraphs), I improved my writing skills in many ways such as the grammar, coherence, unity and content in a writing.

P79: We always did our homework by writing. Even our communication with the lecturers was in written language. I can say that my writing skills have improved as I was constantly searching for new words and phrases to include in my homework.

P2: I believe distance education improved my speaking a lot because I started to watch and listen myself that's why it has become easier to discover my faults and concentrate on putting right. And I believe that I have become more fluent just because I was obliged to talk 10 min continuously yet at university I talked $3 \mathrm{~min}$ with intervals.

In addition to this, the nature of the midterm and final exams are also mentioned underneath the first theme of the content and implementation of online courses. The way that the midterm and final exams and evaluations were conducted during EDE also affected the improvement of language skills of pre-service EFL teachers. It is highly associated with the influence of evaluation procedures on the development of skills. The extracts below express the participants' opinions: 
P92: Doing the exams as homework let us to read more.

P109: I improved myself to read quicker thanks to my online exams.

The responses of the participants also show that the first theme includes the use of more legible reading materials. This means that, in the virtual environment, it becomes easier and more available for pre-service EFL teachers to read the course materials in this emergency process. The following statements of the participants exemplify this sub-theme better:

P74: Reading materials were clearer since we have them not like copy but on the PC, so they were easy to read.

The second theme related to the advantages of EDE on the development of pre-service EFL teachers' language skills is the comfortable atmosphere of home compared to classroom settings, and the participants felt free from stress resulting in motivation, enthusiasm and willingness for learning more during EDE. Thus, this theme was described by four sub-themes: (a) stress-free, (b) autonomous learning, (c) enthusiasm and willingness for learning, and (d) motivation. Indeed, home was depicted by some participants as stress-free environment in which they felt relaxed and comfortable in order to carry out learning practices for language skills development. Some of the participants reported this advantage of EDE with those words:

P22: Sometimes learners cannot focus on specific texts because of the classroom environment. So at home, we can find a peaceful and silent learning environment to understand what we read.

P11: I enjoyed writing more because I didn't feel stressed, and I was in a comfortable mood to write most of the time.

In addition to the stress-free circumstances, some participants describe how attending EDE at home provided the appropriate environment for pre-service EFL teachers to be more autonomous due to having the opportunity to learn on their own pace. Following extracts demonstrate the second sub-theme, autonomous learning:

P1: I studied all subjects by myself and I understood that even if I think I need someone to teach something to me, I understood that actually I don't need them. I can learn what I want by studying hard easily [for reading skills].

P45: Now that I can set my own pace, and there are no worries about missing a part, I don't have to be alert, which leads to a more focused and relaxed listening.

Due to those circumstances, the participants felt free from stress resulting in enthusiasm and willingness for learning more during EDE compared to classroom settings. It was because of EDE circumstances free from negative emotions such as shyness, anxiety, excitement, or nervousness. This situation was described by the third sub-theme, enthusiasm and willingness for learning, under the second theme. For example:

P22: Sometimes learners cannot focus on specific texts because of the classroom environment. So at home, we can find a peaceful and silent learning environment to understand what we read.

P1: When we are in class, I don't feel comfortable and I generally feel nervous especially in our speaking lessons. I never could express my thoughts and emotions in the way I want. But with distance education, I could speak very well alone in my home. 
P84: It was a good opportunity to practice and improve my speaking skills without excitement at home.

Additionally, due to this comfortable and relaxing atmosphere at home, they became more motivated to conduct effort to develop their language skills, which forms the last sub-theme, motivation:

P90: I get what I should get from an audio record thanks to distance education. I can catch key words or phrases and that stress-free education atmosphere made me more motivated than before [for listening skills].

The third theme that describes the advantages of EDE for sustaining language skills development is free time, referring to participants' spending their free time effectively for language skills progress. Some of the extracts show that, since EDE created some free time that they would not have during face-to face education, they had the chance of spending that free time effectively for the development of their language skills which is defined as the sub-theme time for more skills practice. For this reason, they had more time to conduct skill practices. Here are some extracts:

P11: I think I improved my reading skills because I have a plenty of time to read and search. Also I don't have to create a plan for this activity because I am free whole day. I can read whenever I want. Also, as you know some websites allowed us to access some useful reading materials to encourage people to stay at home. That's why it was a good opportunity to improve my reading skills during the distance education.

P27: I have started to write blog during the COVID-19 pandemic so it was an advantage for me again.

P68: As the COVID-19 pandemic causes us to stay at our homes, we are able to find much time for writing. It is possible because we can keep a diary in English during this pandemic; so we can develop our writing skills or we can write what we have understood from our reading, summarizing it. Another thing about writing is to summarize what we've read via the internet or stage books, novel or magazines, etc.

P11: I have enough space and time to read aloud at home to improve my pronunciation skills. I can also speak to myself even though it may sound like a crazy.

The fourth theme concentrates on the properties of distance education platform. This theme is organized around two sub-themes: (a) time and place free nature of materials and online lessons and (b) repeated watching availability of online lessons. Considering the content of the extracts related to the advantages of EDE, they show that, whatever the platform is, the participants reflect no advantage from those platforms for speaking skill, while for the development of listening skill, this theme is the most highlighted one. The sub-theme time and place free nature of materials and online lessons refers to the efficiency of the system that pre-service EFL teachers could access whenever and wherever they wanted, and one participant explains this advantageous side of EDE for reading skills by stating that,

P6: You have access to reading material online and you can utilize it with every electronic device everywhere at any given time.

Additionally, the other sub-theme is repeated watching availability of online lessons, and it refers to flexible use of recordings of online courses in platform. Thus, some participants stated the chance of watching the online lessons again and again whenever they wanted. Some samples of the extracts pinpointing this advantage of watching online lessons repeatedly are:

P104: If we don't understand the paragraph type while doing our lesson, we can watch the record of the lesson [for writing skills]. 
P49: We got a lot of chance to listen to the lecturers carefully. Even if we didn't understand, we could always watch the lesson from the archive.

The next theme, use of computer/ online tools /resources, makes reference to the availability of electronic devices and a wide range of online tools and resources in the virtual environment for the development of language skills. This theme includes two sub-themes: (a) wide variety of resources on the internet and (b) use of online tools (dictionaries, etc.). The wide variety of resources on the internet indicates the great range of resources, activities and materials pre-service EFL teachers can benefit from. During EDE, the internet provided a virtual environment for pre-service teachers, including various resources to accelerate their skills development. Some participants stated that,

P6: When I am in front of a PC, I feel like I can use my imagination freely because I have limitless access to internet so if I want to check something or need inspiration it's easy to find what I need [for writing skills].

P101: You can watch many things. For example, you can watch films or news, and by doing activities like these things, you can improve your speaking.

The second sub-theme associated with use of computer/ online tools/resources is use of online tools (dictionaries, etc.), pointing to various applications and online programs such as online dictionaries or programs for spelling, pronunciation, and grammar correction. Some of the participants highlighted this advantage of EDE:

P3: You can use online dictionaries easily while reading.

P2: Thanks to the Microsoft apps, because they show the mistakes you did, so you pay more attention [for writing skills].

P51: When a person doesn't feel relaxed among people, this person can join online conversations. So, it makes people feel good [for speaking skills].

The sixth theme is the time and cost-efficient aspect of EDE, in which the participants stated they saved their time and money through the use of EDE during the COVID-19 pandemic, and the process accelerated their skills development. This theme is structured by two sub-themes: (a) saving time and money and (b) use of a keyboard. Saving time and money indicates that, due to the fact that education was conducted online during the COVID-19 process, students did not have to waste their money and time. Some participants stated that they could spend the time and money they saved to develop their language skills. Additionally, it was much faster to reach resources on the internet to study for language skills development. Here are some extracts clarifying saving time and money:

P39: I have more time to read and I don't have to waste my energy in bus. Also I can find more resources on the internet it is much faster.

P57: When I consider the face-to-face education, reading materials and articles were limited for me since I always had to pay to get a hard-copy of a material. However, with the help of distance education, I was able to reach the PDF and other materials easily without a problem.

P33: Distance education provides more time and opportunities for us students compared to traditional methods (face to face education). I sometimes travel $2.5 \mathrm{~h}$ for a two-hour lesson in school, and the strangest part is that the outcome of a two-hour lesson at school takes $10 \mathrm{~min}$ at home to learn [for listening skills, translated].

P6: Everything else was awesome and I sincerely believe that Turkish education system should embody online education as primary way of education. It saves so much time that you can actually work on things you need to [for speaking skills]. 
The second sub-theme, use of a keyboard, reflects the extensive use of a keyboard for carrying out their EDE practices and tasks, which accelerates the progress of their language skills.

P6: Being able to work with a keyboard allows you to write fast and you can get it done quickly.

Teacher's role emerged as the seventh theme but only for writing skills. This theme is comprised of the sub-theme feedback, referring to the importance of getting regular feedback for the progress of writing skill:

P94: The professor was always checking the works and she always gave feedbacks [for writing skills].

P107: Because of our teacher, our writing course was both enjoyable and beneficial. During this distance education period, we learnt what we were going to learn in face-to-face education without experiencing any difficulties. I think this situation is true for every student who participated to the course [translated].

In the comments and responses, the percentage of the participants who remarked that they did not encounter any advantages of EDE for language skills development cannot be ignored easily, especially for speaking skills $(45 \%)$. Thus, this situation is described by the eighth theme, no advantage.

P4: Because I was at home all the time and I didn't have a chance to make practice. So, it became worse and worse... [for speaking skills].

P6: You can't communicate vocally [for speaking skills].

Additionally, some comments do not present any clues or codes related to the advantages of EDE. Thus, the last theme is no answer, representing the existence of no appropriate answers presented by the participants for the advantages of EDE on the development of language skills.

\subsection{Disadvantages of EDE on Language Skills Development of Pre-Service EFL Teachers}

The third question of the questionnaire asked pre-service EFL teachers about the disadvantageous aspects of EDE for the development of each skill. Underneath each skill in the online questionnaire, enough space was provided so that the participants could write the negative aspects associated with EDE in detail. With regard to the disadvantages encountered during EDE, the participants concentrated upon nine themes: the content and implementation of online courses, absence of a face to face classroom environment, insufficient teacher guidance, reading/writing on a computer, tablet or a phone, technical issues, lack of individual effort, the shift in the medium of communication from speaking to writing, no disadvantages, and no answer. Across those nine themes, there are 36 sub-themes. Table 2 depicts these nine themes, related sub-themes, and the frequencies and percentages of themes associated with each skill in detail. As it can be seen in the table, the participants put forward the disadvantageous aspects of EDE through a total 130 comments for reading, 121 for writing, 127 for listening, and 157 for speaking skills.

Table 2 demonstrates that the theme with the highest percentage is no disadvantages for reading $(37 \%)$, writing (36\%), and listening (30\%) skills; in other words, those participants felt that EDE had no disadvantages for sustaining development of their reading, writing, and listening skills. Nevertheless, the same cannot be uttered easily for speaking skills, as the theme with the highest percentage is content and implementation of online courses (38\%). For listening skills, technical issues carry the same importance for disadvantage category with the same percentage $(30 \%)$ of no disadvantages. Each theme and sub-themes underneath for disadvantages of EDE are explained in the following paragraphs with accompanying example sentences of the participants. 
Table 2. Summary of TA for the Disadvantages of EDE for Sustaining the Development of Reading, Writing, Listening, and Speaking Skills.

\begin{tabular}{|c|c|c|c|c|c|c|c|c|c|c|}
\hline & \multirow{2}{*}{ Themes } & \multirow{2}{*}{ Sub-Themes } & \multicolumn{2}{|c|}{ Reading } & \multicolumn{2}{|c|}{ Writing } & \multicolumn{2}{|c|}{ Listening } & \multicolumn{2}{|c|}{ Speaking } \\
\hline & & & $\mathrm{f}^{1}$ & $\%$ & $\mathrm{f}$ & $\%$ & $\mathrm{f}$ & $\%$ & $\mathrm{f}$ & $\%$ \\
\hline 1 & $\begin{array}{l}\text { Content and implementation of } \\
\text { online courses }\end{array}$ & $\begin{array}{l}\text { Lack or insufficient amount of skills-based } \\
\text { content; amount and deadlines of homework; } \\
\text { delivery of exams; materials used }\end{array}$ & 16 & 12 & 19 & 16 & 24 & 19 & 59 & 38 \\
\hline 2 & $\begin{array}{l}\text { Absence of a face to face } \\
\text { classroom environment }\end{array}$ & $\begin{array}{l}\text { Desire for being in a classroom setting; feelings of } \\
\text { belonging to a group; lack of peer interaction; } \\
\text { lack of eye contact; absence of a } \\
\text { suitable/comfortable atmosphere at home; lack of } \\
\text { listening to or speaking English within the } \\
\text { immediate environment }\end{array}$ & 19 & 15 & 9 & 7 & 15 & 12 & 40 & 25 \\
\hline 3 & Insufficient teacher guidance & $\begin{array}{l}\text { Lack of (or insufficient) communication with the } \\
\text { teacher; lecturing style of the teacher; need for a } \\
\text { professional guidance; lack of (or insufficient) } \\
\text { feedback; need for prompt answers; absence } \\
\text { of authority }\end{array}$ & 11 & 8 & 25 & 21 & 5 & 4 & 6 & 4 \\
\hline 4 & $\begin{array}{l}\text { Reading/Writing on a computer, } \\
\text { tablet or a phone }\end{array}$ & $\begin{array}{l}\text { Eye problems; loss of concentration; tiresome; } \\
\text { online exams; preference for pen and paper; } \\
\text { typing problems }\end{array}$ & 18 & 14 & 9 & 7 & - & - & - & - \\
\hline 5 & Technical issues & $\begin{array}{c}\text { Internet connection problems; } \\
\text { lack of computer; sound problems (microphone, } \\
\text { audio/ video lag); problems caused by distance } \\
\text { education platform (uploading, capability, etc.); } \\
\text { quality of the recordings }\end{array}$ & 9 & 7 & 6 & 5 & 38 & 30 & 29 & 18 \\
\hline 6 & Lack of individual effort & $\begin{array}{c}\text { Self-criticism; less motivation; } \\
\text { time management problems; } \\
\text { irresponsibility; passive learner; } \\
\text { lack of self-discipline and integrity; persistence in } \\
\text { study habits; technological illiteracy }\end{array}$ & 6 & 5 & 7 & 6 & 4 & 3 & - & - \\
\hline 7 & $\begin{array}{l}\text { The shift in the medium of } \\
\text { communication from speaking } \\
\text { to writing }\end{array}$ & $\begin{array}{l}\text { Participation to online courses via written } \\
\text { communication instead of verbal }\end{array}$ & - & - & - & - & - & - & 4 & 3 \\
\hline 8 & No disadvantages & & 48 & 37 & 44 & 36 & 38 & 30 & 15 & 10 \\
\hline 9 & No answer & & 3 & 2 & 2 & 2 & 3 & 2 & 4 & 3 \\
\hline & $\begin{array}{l}\text { TOTAL (frequencies are more than } \\
118 \text { since some responses of } \\
\text { the participants included more than } \\
\text { one theme) }\end{array}$ & & 130 & 100 & 121 & 100 & 127 & 100 & 157 & 101 \\
\hline
\end{tabular}

The first theme in Table 2 is content and implementation of online courses, and while it may be a disadvantageous factor for reading (12\%), writing (16\%), and listening (19\%) skills, it is the most disadvantageous one for speaking skills (38\%). There are four sub-themes underneath: (a) lack or insufficient amount of skills-based content, (b) amount and deadlines of homework, (c) delivery of exams, and (d) materials used. For the first sub-theme lack or insufficient amount of skills-based content, the participants stated that either that specific language skill was not highlighted enough within the course content or it was totally missing, as conveyed through the following statements:

P21: We didn't make progress about it. We could have practiced at least. Assignments were based on skimming, and so we just read articles for a general purpose, not for researching.

P74: The problem is that there were no listening skills practices in the distance education besides teacher voice.

P68: In the normal education (face to face education), there is a classroom atmosphere thanks to "real participants" (teacher and students) who are an observer and participant each, so there is a communication between them. This helps them to speak each other. But in the distance education, the person who speaks all the time is the teacher. For this reason, we-as students - cannot find any opportunity to join the lesson with our speaking ability. Therefore, I think this situation has a negative effect on students when we think about speaking skills. 
The second sub-theme emerged is amount and deadlines of homework, and while most of the participants highlighted that there was too much homework, few participants complained about the inefficiency of the content of the homework:

P1: We have 10 different lessons and almost all of our teachers gave different homework every week in this process. Sometimes I felt really very tired doing all this homework and sometimes I could not finish all my homework before the deadline. Sometimes I didn't sleep for my homework. Of course all of these things affected me negatively [for reading skills].

P83: Teachers don't give enough reading material. I am assuming most of them just don't care, or they think the students would hate it or whatever so they want to avoid conflict.

P74: Too much writing skills were highlighted. The only problem is that it was too much used in homework, and our teachers or the system acted like there was just writing skills that we should work on.

Delivery of exams is the third sub-theme, and participants focused on the disadvantageous effect of how exams were delivered together with how assignments replaced exams:

P68: Before the pandemic, we-as students-were examined in the paper based exams, so we were supposed to write the answers down the papers within the limited time the teacher fixed before; so this situation expected us to think the knowledge about the questions and write the proper answers quickly. But during the pandemic, the teacher mostly gave us paper based assignments and they spread the deadlines of assignments for a very long time. For these reasons, the distance education may have a negative effect on students.

P55: We had problems with online exams; the other things were fine [for listening skills, translated].

The last sub-theme is about the kind of materials used for online courses during EDE, and participants mostly focused on this sub-theme with regard to reading skills and the length of the reading materials:

P59: Some of the texts that we have read were too long, and we lost concentration and had to read again.

P85: Some classes sometimes included long materials, about 5 or more pages long ones with extreme details or academic languages. And we had to read most of them through the screen which was tiring a lot.

The second theme in Table 2 for disadvantages brought by EDE is absence of a face-to-face classroom environment. This theme seems to affect speaking skills (25\%) more than reading (15\%), writing $(7 \%)$, and listening (12\%) skills. There are six sub-themes: (a) desire for being in a classroom setting, (b) feelings of belonging to a group, (c) lack of peer interaction, (d) lack of eye contact, (e) absence of a suitable/comfortable atmosphere at home, and (f) lack of listening to or speaking English within the immediate environment. Participants especially expressed their desire for being in a classroom setting, which proves the pivotal role of face to face classroom settings in students' lives and which can easily be traced from the following statements:

P28: I miss speaking in English with my friends; distance education is very bad about this subject. Face to face learning is better than online learning over speaking skills.

P118: As we are not in a classroom setting and that is why we could not see each other (classmates), sometimes we could interrupt each other and it is annoying. It does not feel as in the classroom because the communication is better when it is face to face [for speaking skills]. 
Closely related to the previous sub-theme, feelings of belonging to a group were emphasized as one of the disadvantageous sides of EDE. In other words, pre-service EFL teachers wished to be within a social group rather than attending online classes individually, demonstrating a need for camaraderie.

P3: I like to participate in class but we did everything individually [for reading skills].

P12: Active listening builds strong relationship and communication skills. The pandemic has created message where you can not actively reflect back to a person who you are listening to and reflect on what's been said, you show that you've been listening not just hearing but genuinely understand the feelings or messages they are trying to convey.

P65: Not being able to form a regular classroom atmosphere causes problems in developing listening skills efficiently [translated].

P24: It was not efficient like the face to face speaking. Classroom environment is important for us to take lessons seriously.

The next sub-theme is lack of peer interaction, which indicates the collaborative aspect of the face-to-face classroom environment. This sub-theme demonstrates how participants needed one another in the educational contexts:

P100: I was writing in class and getting feedback from my friends before Corona virus, but I could not get this same atmosphere in online classes.

P82: During face to face learning, you can be more relaxed by trusting your classmates on the instructions, or lectures given by the teacher. However, at home, you have less chance to ask your classmates about what the teacher said at any particular moment [for listening skills].

One of the most crucial dimensions of classroom communication is forming eye contact, and lack of eye contact was pinpointed by the participants as a barrier, especially for developing listening and speaking skills:

P44: It is always better to listen to our teachers face-to-face by having eye contact [translated].

P30: In class, you got limited time and you have to think and answer directly but in online education it's not the way how it goes. Talking with a person face to face and talking to a screen is different.

Another sub-theme is the absence of a suitable/comfortable atmosphere at home, where the participants cannot concentrate on their studies efficiently.

P22: Some learners may not find a peaceful environment to read and understand the texts at their home.

P57: Even though I was able to reach any material that I needed, because of distractions in my home, I couldn't focus enough and that affected my reading.

P77: I had noise in the environment during online class no clear understanding possible [for listening skills].

The last sub-theme for the second theme in the table again focuses on their immediate surroundings and highlights the fact that there is a lack of listening to or speaking English within the immediate environment. 
P23: I listened to my lessons but I had no opportunity to improve it because there was no one who knows English in the house.

P34: I had no advantage in terms of speaking skills since there was nobody around. The biggest issue is this virus infects everyone. So when nobody around to talk, this is so boring not only to improve the speaking skills but for communicating.

The third theme emerged from the data is insufficient teacher guidance, which reveals the role of the teacher in the educational processes. The skill that was affected negatively the most from this theme appears to be writing with the highest percentage $(21 \%)$ among the other skills. There are six sub-themes: (a) the lack of (or insufficient) communication with the teacher, (b) the lecturing style of the teacher, (c) the need for a professional guidance, (d) the lack of (or insufficient) feedback, (e) the need for prompt answers, and (f) absence of authority. The following statements elucidate the first sub-theme-lack of (or insufficient) communication with the teacher-better.

P115: I'd like to know which words I mispronounced. If we were in school, the teacher would say it directly, but this was not possible because of distance education [for reading skills].

P93: When I had a problem or a question in writing something, I had little chance to reach my teacher and talk with her effectively.

The lecturing style of the teacher is another sub-theme that might demonstrate what participants needed in online courses.

P82: Most of the lecturers didn't do their best to involve in the students, or pushed students to speak.

Participants also articulated their need for a professional guidance through the following statements:

P66: The only problem I have experienced about my reading skill during this pandemic is not being able to contact with my teachers easily. For example, I have read an article but I didn't get some parts and because of the pandemic, I couldn't contact with my teachers.

P98: I didn't have so many problems with regard to the development of the writing skills, but for some assignments it would definitely be better to have more input and support provided in advance.

Next sub-theme is the lack of (or insufficient) feedback that the participants perceived as one of the disadvantages of EDE.

P84: Writing skills is a lesson that requires feedback from the lecturer. So, not being able to contact the lecturer was a negative feature.

P14: We didn't have feedback from our listening teacher.

Closely associated with feedback, the need for prompt answers is another sub-theme touched upon by the participants.

P84: In face-to-face education, it was easier to see and learn how words are pronounced exactly, and receive instant feedback on mistakes made by the students. So, this was not possible with distance education [for listening skills].

P96: When I misunderstood my teacher, I could not ask it at the same time, and sometimes I realize very late that I misunderstood something [for listening skills]. 
The last sub-theme identified is the absence of authority, which clearly indicates the demand of the participants for a more controlled and authoritative online atmosphere.

P89: Teacher doesn't control whether the students write or someone else.

P38: We could have improved more if the all the students were on camera with the teacher at lesson time [for speaking skills].

P100: There was no discipline that much because we were attending classes online [for speaking skills].

In Table 2, the fourth theme regarded as a disadvantageous side of EDE is reading and writing on a computer, tablet or a phone, which should affect only reading $(14 \%)$ and writing $(7 \%)$ skills development. The six sub-themes below this theme are (a) eye problems, (b) loss of concentration, (c) tiresome, (d) online exams, (e) preference for pen and paper, and (f) typing problems. The following statements reveal the first sub-theme-eye problems—clearly:

P39: Computer monitor is not good for eyes and it is not so practical [for reading skills].

P51: I have some problems with my eyes so it was difficult for me to read online sources. Also, I have a difficulty to understand what I read. I couldn't concentrate on something while reading. It was distracting for me.

Loss of concentration, which arose as the next sub-theme, is highlighted in the following statements:

P8: Reading online is more distracting than reading physically

P48: Reading the course materials on the Internet affected me badly because I generally prefer reading textbooks and they are more effective for me to understand. On the Internet reading, I couldn't focus on the topics.

Participants also pinpointed that reading online is a tiresome process for them:

P85: Some classes sometimes included long materials, about 5 or more pages long ones with extreme details or academic languages. And we had to read most of them through the screen which was tiring a lot.

P45: Some students, like me, did not have their books and such so we continuously had to read from a computer or phone screen. That was a serious problem for me.

Online exams were perceived as one of the disadvantageous aspects of EDE due to the duration, typing, etc.

P109: I had some difficulties in my exams to read fast. I sometimes got bored to read in front of my computer.

P40: Typing and handwriting are very different from each other. I myself hate typing and online exams really forced me; I couldn't use my time properly [for writing skills].

P73: The duration of the exam was not enough to answer the questions [for writing skills].

Some participants complained about reading and writing on technological devices since they had a preference for pen and paper.

P80: I actually don't like using technological devices. I'm kind of conventional and this situation made me feel worse when I read all things on my computer that's why I even thought that I was going to be blind : 
P11: I am a bit old-fashioned person, so sometimes I have difficulty with writing my answers and expressing my thoughts when the teacher expects me to answer. I like writing by using pen and paper more, and writing in the classroom activities seems more effective to me.

P80: I hated to do lessons on my computer without using paper and my lovely pens. Therefore, the process was so difficult when I had to get used to technology more, and in the beginning I avoided using it, so this got me demotivated [for writing skills].

The last sub-theme of the fourth theme is typing problems encountered for writing.

P8: Typing errors and lack knowledge of office programs are annoying for writing activity.

P51: It took time more than enough to write files or homework. Because it always needs to adjust size, colours, etc.

P64: We can come across with an application error while writing homework or maybe we cannot write the way we want in terms of structure.

Table 2 illustrates that the fifth theme is technical issues with the accompanying five sub-themes: (a) internet connection problems, (b) lack of computer, (c) sound problems (microphone, audio/video lag), (d) problems caused by distance education platform (uploading, capability, etc.), and (e) quality of the recordings. The participants expressed that these issues especially affected their listening skills $(30 \%)$ development, and then speaking skills $(18 \%)$, followed by reading $(7 \%)$ and writing $(5 \%)$ skills. Internet connection problems are the most important technical issue among the others:

P11: Sometimes we have connection problems about the internet or the system and we cannot even hear the teacher or classmates well. It causes wasting the lesson time, and I totally get distracted [for listening skills].

P85: We didn't have the chance to speak. Even if we had, connection problems would constantly cut our voice, which happened with many teachers in every week.

Lack of computer is another sub-theme which was regarded to impede development of skills:

P107: Since we did not have the textbooks, our teacher sent the articles or other sources online, and I had to open the book from my phone and attend the class from a computer. However, since I do not have a computer, it was difficult to read, write, and respond using my phone [translated].

P26: I had problems caused by my old computer while writing.

The next sub-theme is sound problems (microphone, audio/video lag), which hindered listening skills development:

P40: Some instructors' microphones were not good enough therefore I preferred to watch some lessons from archive records by stopping and playing every moment that I couldn't understand [for listening skills].

P76: Minor sound problem because of the microphones used by some instructors [for listening skills].

P103: There was a synchronization problem in classes [for listening skills].

Some participants focused on the problems caused by the distance education platform (uploading, capability, etc.) as another sub-theme via the following statements: 
P45: As we listen, sometimes the platform doesn't work properly, and we are interrupted, it can be frustrating.

P1: I had some problems in this course especially in sending my voice records and videos. Because the distance education system was new, it could not accept heavy files. For example, we could just send a voice record that was $8 \mathrm{MB}$. It caused some problems. For instance, because the "MB" was limited, we could not express our all thoughts in a good way or we could not speak everything we wanted about the subject that was sent by our teacher.

P59: We weren't able to speak most of the time due to the app that we use. The application doesn't allow all the students to speak.

P78: The system doesn't support oral participation at all. This is not a good method for language teaching process [for speaking skills].

The fifth sub-theme of technical issues is the quality of the recordings, which might have been thought to be related to the flexibility aspect of EDE while creating troubles for some students, as in the following sentences:

P38: Since technical problems aroused during online classes, I failed to listen to instructors properly from time to time. Moreover, when I couldn't enter some lessons on time, some of the recorded lessons did not play due to the online system problems.

P41: The lesson records may not be well recorded [for listening skills].

Another theme in the table is the lack of individual effort, for which the participants criticized themselves (except for speaking skills) and took responsibility for disadvantages in writing skills development $(6 \%)$, followed by reading $(5 \%)$ and listening $(3 \%)$. Sub-themes for this theme are (a) self-criticism, (b) less motivation, (c) time management problems, (d) irresponsibility, (e) passive learner, (f) lack of self-discipline and integrity, (g) persistence in study habits, and (h) technological illiteracy. The first sub-theme—self-criticism—can be discerned in the examples below:

P106: For me, I tried to handle my assignments with less reading. I couldn't improve my reading any because I didn't try.

P117: I just focused on listening to lessons and unfortunately nothing more.

The next sub-theme is less motivation demonstrated through the followings:

P83: I know for majority of the students; it has the reverse effect because not everyone is motivated to be their better selves [for reading skills].

P114: Because I have not focused my lesson effectively. I got demoralized by this situation [for reading skills].

Time management problems constitute another sub-theme for disadvantages section:

P15: The only problem is that since there is not discipline, I take it easy and forget the deadlines. This situation prevents me from writing faster [translated].

Irresponsibility emerged as one of the sub-themes can be sensed through these statements:

P117: Reading skills mostly depended on us so I couldn't read English. I couldn't spend enough time for reading. Rather, I tried to deliver my exams' works and was busy with them. 
P112: Since students do not feel strict responsibility during distance education, they do not focus on developing their writing skills. In addition, those skills are used only for homework, so they cannot be improved and instead they stay the same [translated].

The participants also mentioned they did not take action toward the objectives but remained passive learners:

P107: I was not an active participant for the lessons [for reading skills].

P4: Even in normal times, I have bad listening skill, and during this time, I didn't do anything to improve it. So, it became worse. At some points, I didn't understand even what my teacher had said. It was terrible for me. In normal times, at least I listen to some listening passages at lecture, but at home, I listened nothing apart from online class. And it wouldn't be enough.

Next sub-theme is lack of self-discipline and integrity, for which the participants found faults in themselves.

P22: Unfortunately, some learners may cheat themselves by using a copy-paste trick [for writing skills].

P67: Because I have mostly used computer (copy \& paste) to prepare my homework, I can't put anything on my writing skills.

P15: As there are no strict rules in distance education, I work on the listening activities without forcing myself and according to my own pace, not in such a way as to develop my skills. For instance, I listen as much as I want. This situation affects me negatively in attaining better listening skills [translated].

For a few students, it was not so easy to change their routines, despite the reality around them; as a result, persistence in study habits emerged to be one of the sub-themes here.

P45: Personally, I choose to write very brief paragraphs. And that's not something ideal for distance education when we are mostly graded by our writing.

The last sub-theme is technological illiteracy, for which few participants felt the need to prioritize.

P83: We need to learn how to use technology better [for listening skills].

The seventh theme in Table 2 is the shift in the medium of communication from speaking to writing, and this was mentioned for speaking skills development only. Although it does not have a significant percentage (3\%), it is worth mentioning because this theme is closely related to content and implementation of online courses for which the speaking skills has the most disadvantages ( $38 \%)$. The sub-theme here is participation to online courses via written communication instead of verbal, and it can be observed in the following statements:

P36: Since we participated in lessons only by writing, it has lots of disadvantages for speaking skills [translated].

P42: There was a limited interaction. We could not talk, we could just write and because of my internet connection I was very slow at it, I could not even participate, ask or answer questions.

P98: I believe that we didn't have so much chance to practice our speaking skills, we would only answer some questions provided by the teacher(s), and it was easy not to participate for some of the students since there is no eye contact with the teacher or we could simply write rather than speaking. 
The eighth theme in the table is no disadvantages, and as a percentage, it seems that the majority of the participants reflected that they did not experience any disadvantageous aspect of EDE for sustaining reading $(37 \%)$, writing (36\%), and listening (30\%) skills development, yet the situation may not be true for speaking skills (10\%):

P4: There wasn't any negative effect about reading skills.

P83: There was no problem regarding my writing skills.

P70: I did not realize any problems about listening skills during the distance education.

The last theme in Table 2 is no answer caused by the fact that a few students either wrote an inappropriate answer for the questions or wrote the same question again as a response.

\subsection{The Most Positively and Negatively Affected Skills}

The third and the fourth patterns gathered by TA show the most positively and negatively affected skill during the COVID-19 pandemic process by EDE. The most positively affected skill and the most negatively affected skill were determined through the use of different patterns (the second and the fourth questions in the Appendix A) based on two research questions. This is because the least positively affected skill does not match the most negatively affected skill during EDE. Additionally, the responses of some participants identified more than one skill. Thus, the frequency of comments related to each of these patterns is more than the number of the participants. The thematic structures of two patterns are the same, but the frequencies and percentages for the themes vary. For ease of comparison, a summary of those two patterns is presented in the same table, as seen in Table 3.

Table 3. Summary of TA for the most positively and negatively affected language skills during EDE.

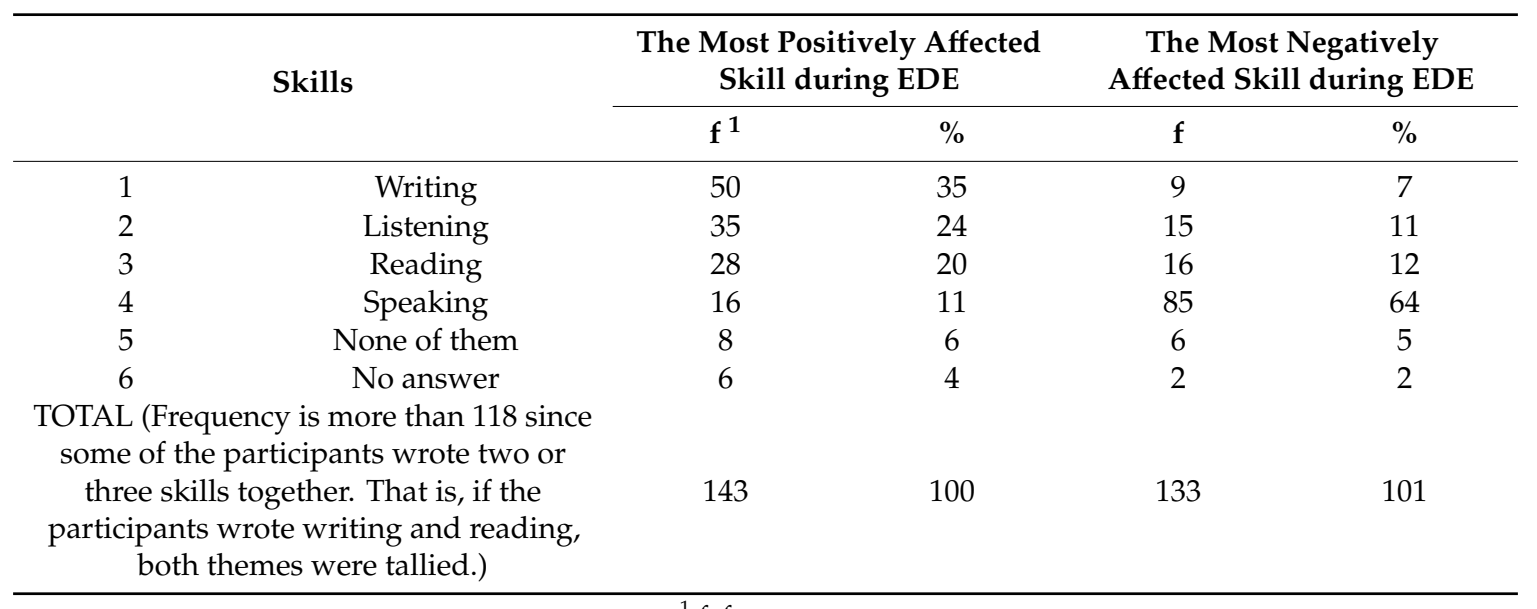

${ }^{1}$ f: frequency

Table 3 summarizes the findings of TA analysis regarding the most positively and negatively affected skill. Those patterns include six themes: (a) writing, (b) listening, (c) reading, (d) speaking, (e) none of them, and (f) no answer. It is apparent that, while the theme writing is identified as the most positively affected skill, with only $35 \%$, the theme of speaking stands out as the most negatively affected skill, with a much stronger stress $(64 \%)$ over the other themes. The ordering of the skills for positive and negative effect also highlights this outcome. While writing has the highest percentage for the first column, it has the least for the second column. The same situation holds true for the fourth theme speaking in the opposite direction. The placement of themes of listening and reading within the columns has the same tendency as well. Thus, the frequencies of the themes generated for the pattern of the most positively affected skill show writing, listening, reading and speaking, in that order during the COVID-19 emergency circumstances with EDE. Additionally, the responses 
of the participants for the description of the most negatively influenced skill demonstrate speaking, reading, listening and writing, in that order. This means the descriptive statistical information about the thematic structures of those patterns verify each other.

\section{Discussion}

The onset of COVID-19 created an unsustainable environment for all educational systems by endangering the quality of education (SDG 4). The emergency circumstances of the pandemic hinder the fulfilment of the right of education. At this point, the absence of quality education (SDG 4) due to the COVID-19 interruption might impact development, "as people's productivity and creativity will face barriers" [25] (pp. 7-8). Thus, e-learning or online learning and teaching practices regarded as EDE were immediately popularized. However, it is known that EDE makes some "vulnerable students in need of basic shelter, clothing, and lacking access to the internet disadvantaged" [8] (p. 108). Those inequalities threaten quality education (SDG 4). Considering those perspectives, the discussion conducted in this study does not focus on whether the sustainability of language skills development of pre-service teachers is weak or strong; rather, it gives voice to one group of EDE learners to understand how these emergency circumstances can be improved to overcome the absence of quality education and what the stakeholders can learn. In this respect, the present study sought to answer four research questions focusing on how EDE is advantageous and disadvantageous for sustaining the development of each of the four language skills and which skill has the most and the least advantage under the emergency circumstances. Each section of the questionnaire served as a cross-check of the answers of the participants; thus, rather than acting as separate sections, they complemented each other.

\subsection{Research Question One}

What are the advantages of emergency distance education on sustaining language skills (reading, writing, listening, and speaking) development of pre-service EFL teachers?

Thematic analysis showed that advantages of EDE can be grouped around nine themes: content and implementation of online courses, comfortable atmosphere of home, free time, properties of distance education platform, use of computer/online tools/resources, time and cost efficiency, teacher's role, no advantages, and no answer. All these themes show some parallelism with the five primary topics in the road map of distance education created on 17 March 2020 for Turkish universities: curriculum, infrastructure, human resources, content, and implementation [23]. It should be kept in mind that the content and implementation of online courses emerged as a theme in both the advantages and disadvantages section of the questionnaire, proving the fact that, if it is used properly and efficiently, the same theme can easily be transformed into an advantage to ensure a better online educational setting. In addition, although teacher's role or guidance was analyzed as a separate theme; the teacher is the only actor (most of the time) behind the content and its implementation. Interestingly, some participants stated that EDE could have advantages for speaking skill depending on the way the online courses are implemented. If teachers provide an interactive virtual environment and more peer/group activities, they believe that they can improve their speaking skills. This means that the content and implementation of the courses is associated with their effectiveness [17]. All the results indicate the importance of the status and responsibilities of the teacher in course design and implementation. In fact, teachers play a prominent role in the COVID-19 crisis, since they can "not only intervene with regard to knowledge and experience but also unavoidably exercise power in relation to that knowledge" [42] (p. 4). Besides, some of the participants highlighted the importance and positive atmosphere of their home which is free from negative emotions such as shyness, anxiety, excitement, nervousness, etc. They believe that, when they interact verbally in a virtual environment, they feel more comfortable and relaxed due to the removal of those negative feelings. Considering the comfortable atmosphere students have at home, EDE also offers self-paced learning for students and fosters their motivation, which is also supported by the literature $[6,58,59]$. Additionally, EDE led the participants 
to use computer/online tools/resources, including various applications and online programs, such as online dictionaries and programs for spelling, pronunciation, and grammar correction. With EDE, some participants could also save their money and time, which provided more opportunities to develop their language skills.

Another facet of distance education is that it necessitates more responsibility on the part of the learners because of its independent study mode [60]. This situation was reflected by some of the participants as both an advantage and disadvantage of EDE. It is advantageous since learners have more free time for developing their language skills (e.g., reading the books waiting to be read on their shelves or creating a blog and writing there regularly), which might be signs of learner autonomy and self-thriving. Another advantageous aspect of EDE is related to the properties of distance education platforms that provide access to course materials with temporal and spatial flexibility $[6,58]$. Through the use of the EDE platforms, pre-service EFL teachers can access the recordings and materials of the courses whenever and wherever they wanted, which demonstrates an advantage mostly for listening skills (22\%) but none for speaking. Supporting this outcome, nearly half of the participants $(45 \%)$ thought that EDE had no advantages for their speaking skills development.

\subsection{Research Question Two}

What are the disadvantages of emergency distance education on sustaining language skills (reading, writing, listening, and speaking) development of pre-service EFL teachers?

The results of TA revealed the disadvantageous dimensions of EDE with the following nine themes: content and implementation of online courses; absence of a face-to-face classroom environment; insufficient teacher guidance; reading/writing on a computer, tablet, or a phone; technical issues; lack of individual effort; the shift in the medium of communication from speaking to writing; no disadvantages; and no answer. Data analysis of the "disadvantages section" demonstrates parallel results with the "advantages section." For speaking skills, the participants stated that the main problem lay in the content and implementation of the online courses (38\%) in which they had little or no speaking practice compared to face-to-face educational settings. This, in turn, affected them into mentioning the absence of a face-to-face classroom environment in which they desired to be placed. The shift in the medium of communication from speaking to writing also deteriorated the situation. Despite the fact that it is very hard to conduct interactive L2 speaking activities and practice using virtual educational platforms with more than four to six students [40], numerous participants put forward their desire for oral interaction during EDE. While the participants viewed EDE as having no disadvantages for the other three skills with $30 \%$ or more, it is only $10 \%$ for speaking skills. Reading and writing on a computer, tablet, or phone emerged as problematic for reading and writing skills because it may cause eye problems, loss of concentration, etc. For the development of listening skills, technical issues created disadvantages. Inadequate technological equipment and connection problems were disadvantages put forward by the participants. Similar challenging situations were also mentioned by other studies $[14,59,61]$. The students who had internet access and technical tools were more inclined to comply with the EDE requirements. Nevertheless, without overcoming the digital inequalities and problems, the same quality of online education cannot be provided for every student [11]. In Turkey, "students from low-income social groups were the ones most affected from the digital divide and unequal opportunities because the current emergency remote education practices adopted one size fits all approaches" [23] (p. 85). Before implementation of EDE and providing educational opportunities, it becomes more and more crucial to effectively evaluate various variables such as the target group, access to technological tools and devices, and the students' health, social, and economic context. It is unfortunately due to the fact that "the one size fits all understanding does not work anymore" [1] (p. iii), and this situation creates a threat for realizing SDG 4. Focusing on education equality, which is one of the priorities for SDGs and SDG 4, teachers and institutions need to identify the students who are excluded from education and learning opportunities. 
In the disadvantages section of the questionnaire, some participants criticized themselves as lacking individual efforts, except for regarding speaking skills. They put the blame on themselves for being less motivated, irresponsible, passive, and technologically illiterate. They also stated they had some problems with time management, study habits, self-discipline, and academic integrity, which might be caused by the independent study mode of distance education [60]. In order to remove these problems and to be more motivated, the participants expressed that they needed teacher support, which is also suggested in the related literature. Teachers should "demonstrate their emotional presence, build a sense of community, support and care" for their students [23] (p. 86), and thus, a closer teacher-student interaction should be emphasized constantly during EDE $[18,19]$. More importantly, in this time of COVID-19, students have been longing for support and guidance more than ever. Needless to say, insufficient support from teachers can be regarded as a challenge of EDE, since "when things go back to normal, people will not remember the educational content delivered, but they will remember how they felt, how we cared for them, and how we supported them" [1] (p. iii).

\subsection{Research Questions Three and Four}

Which language skill (reading, writing, listening, or speaking) is most positively affected by the emergency distance education for pre-service EFL teachers?

Which language skill (reading, writing, listening, or speaking) is most negatively affected by the emergency distance education for pre-service EFL teachers?

Most of the participants believe that EDE has positive effects on the development of writing skills. Another study also supports the same idea by stating that distance education students "tend to develop their writing and particularly reading skills more than oral and aural skills, in comparison to campus-based students" [62] (p. 24). This might be because the nature of the virtual environment tends to include writing tasks and activities much more than the activities of the other skills. This holds true for the assignments as well. What is more, in the absence of spontaneous interaction-which was the case with the participants in this study-speaking skills cannot be improved efficiently [63]. This situation was also verified by the participants' statements and choices that writing is the most advantageous skill (35\%), while the participants stated with a very high percentage (64\%) that the most disadvantageous skill during EDE is speaking.

\section{Conclusions}

The current COVID-19 pandemic can be regarded as an interruption for the achievements of SDGs. Focusing on SDG 4-quality of education-specifically, it is clear that this interruption has threatened the implementation of quality education and changed the commons of the educational context. In the new commons, the cruciality of EDE lies in the fact that it provides new virtual environments for sustaining learning and education. These new circumstances generated by EDE should be evaluated for many purposes, some of which are,

to identify their impact on students' learning experience; to provide us with insights into how and what the students are learning; to provide us with data on how online practices can be improved; and, finally, to provide an evidence base that can be used by other countries looking to implement online education. [64] (p. 18)

Ultimately, the present study focused on advantages and disadvantages of EDE (caused by the COVID-19 pandemic) on sustaining language skills development. Despite the fact that the findings of the study show inequalities embedded in EDE for the implementation of SDG 4, such as lack of computers, internet connection problems, and the non-suitable learning environment, online education in emergency circumstances offers new, sustainable, and effective learning actions. However, knowing that "a systematic approach in investing, planning, and delivering online learning is an absolute must" [64] (p. 18), the pre-service EFL teachers stated that, if the content and implementation of online courses (materials, assignments, etc.) are suitably organized around language skills development, 
and if the properties of distance education platform allow for the practice for those skills, they will benefit from them sufficiently. Teacher support and guidance, especially in giving feedback, carries importance for them, too. Moreover, EDE is advantageous since it allocates free time for focusing on skills development, provides a comfortable home atmosphere where they feel free from stress, presents time and cost efficiency, and offers the use of online tools and resources. Among the four skills, participants expressed that EDE was most beneficial for writing, since they had to depend on their writing skills for most of their exams and homework. Thus, the increased amount of practice led to the inevitable development of writing skills.

On the other hand, EDE was disadvantageous because the participants missed the face-to-face classroom environment and needed instant teacher support. The students also indicated that they had problems with reading and/or writing on a computer, tablet, or phone. In addition, technical issues increased the problematic aspect of EDE. These aspects are worthy of discussion, especially for speaking skills, since pre-service EFL teachers could find little or no opportunities for speaking English neither at home nor during online courses. If the course was not specifically designed around speaking skills, then the participants felt that the development of those skills was ignored. They also stated that the mode of communication shifted from speaking to writing during EDE, and this situation affected them negatively.

In conclusion, driven by the fact that "highlighting the danger of normalizing emergency eLearning is not the same as condemning all forms of online learning" [2] (p. 501), the present study assures preparedness for EDE in order to sustain language skills development against a possible second wave of the COVID-19 pandemic. For non-native pre-service EFL teachers, language proficiency "will always represent the bedrock of their professional confidence" [65] (p. 254), and language competence is the most essential characteristic of a good teacher [66]. Thus, this study also provides beneficial reflections and insights for educators and universities in restructuring their forthcoming practices and actions for effective delivery of distance education for fostering sustainability of language skills development of pre-service EFL teachers both in the COVID-19 pandemic and post-COVID world.

All in all, the introduction of social distancing as a precaution for the COVID-19 pandemic has radically transformed the current state of quality education (SDG 4). As a solution to overcome the emergency circumstances of the COVID-19 pandemic in the educational context, EDE ensures a continuity in education and learning, although some inequalities are embedded in it. Driven by this perspective, this study highlighted the perspectives and voices of Turkish pre-service EFL teachers about EDE in order to improve and sustain the quality of education regarding the development of their language skills. The participants concluded that EDE procedures might be beneficial for sustaining language skills development to some extent; nevertheless, it creates disadvantages mostly for speaking skills, which was also documented in the field of distance education [67]. Considering the problem of both teachers and students in speaking English within the Turkish context $[37,38,68]$, this issue should be a very important concern of teachers in designing and implementing online classes with the aim of providing paths for sustainable distance education in the future.

\section{Limitations and Suggestions for Further Research}

The results of the present study cannot be generalized for all pre-service EFL teachers in Turkey, but it represents beneficial ideas about the advantageous and disadvantageous aspects of EDE for development of four language skills. During EDE, universities in Turkey have utilized various platforms, but the study does not focus on the differences among those platforms. Diversity in teachers' implementations of their courses could not be taken into consideration as well.

Regarding the suggestions for further research, a study focusing on only one language skill (e.g., speaking) with a larger sampling may enhance our understanding in this field. Even the comparison of two online tools for enhancing a specific skill can be documented. Another suggestion might be to compare the EDE practices of two or more countries for facilitating the language skills of pre-service EFL teachers. Additionally, synchronous and asynchronous practices during EDE 
might be compared so as to portray the points of comparison in detail. This study has pinpointed the importance of the teacher's role and guidance both in choosing the content and implementing it together with supplying feedback. Thus, what teachers felt as to the development of language skills of pre-service EFL teachers during EDE might form the next step of this study with the aim of gathering their perspective from a closer perspective.

\section{Implications and Suggestions for EFL Context}

Though it is not easy to predict what the educational context will be after COVID-19 [2], it is hoped that EDE will reduce the current education problems caused by the COVID-19 pandemic. At this point, what needs to be done is to learn from our mistakes and then plan, design, and implement accordingly [1,48]. Otherwise, in the end, reality might take its revenge [42]. From this perspective, this study has some implications. It is known that pre-service EFL teachers have a certain level of language skills, but they should be provided with constant support and guidance for developing their skills. There are many courses within ELT departments except for those focusing specifically on skills development. Whatever the course content is, the following implications might be very beneficial for pre-service EFL teachers during EDE. The first and foremost implication is about digital literacy. Digital competences such as information and communications technology (ICT) and digital skills of teachers have already been given importance in the field [69]. This pandemic process has elevated the role of digital literacy as a very crucial component of education, especially for EDE contexts. Therefore, teachers should be supported with regular professional development activities focusing on digital literacy. In addition, curricula of ELT departments should be revised to embody courses about ICT, online teaching, and digital literacy for pre-service EFL teachers. In this aspect, social media such as Facebook, Twitter, blogs, and podcasts can be beneficial, as it is demonstrated in the related literature [70] that they can help to develop the four language skills and can easily be adapted into online teaching contexts.

The results of the current research also imply that learning and the development of language skills in virtual contexts could be facilitated by process-oriented activities, collaboration, cooperation, and interaction. The effectiveness and efficiency of EDE is highly related to the implementation and content of the courses. Collaborative online activities contribute to the success of online courses and activities [71] and offer some virtual social environments for students to become active distance learners [16]. Thus, for the development of the four language skills, the model of EDE for EFL contexts should include not only self-instructional materials for independent study but also cooperative and collaborative learning applications enhancing interaction in virtual EFL settings.

These emergency situations might take place in the near future, since it is apparent that COVID-19 will affect the next term(s). Thus, it seems a well-grounded idea for the teachers to have plans for EDE scenarios; that is, their syllabi should be redesigned for EDE as Plan B. In doing so, each language skill should be handled conscientiously — with the motto of "curate before create" - by taking the following points into consideration in order to sustain language skills development:

Reading: During EDE, students were given an abundance of reading assignments, which caused an unnecessary burden; for this reason, the amount of reading homework should be handled with care. Teachers might cooperate and assess the amount of homework together. In addition to the amount of homework, the content of the homework carries importance, too. Instead of repetitive, similar types of homework, teachers might choose to include various enjoyable assignments and even provide alternative reading texts so that students might feel that they have a say in the course. Too much reading on screen can create health problems, especially for the eyes. In fact, some of the students do not like reading on a screen; they want to feel real paper and books. To overcome this, first, the texts used during online education should be legible, and if possible, materials that are to be used for the term can be printed out and distributed. Because seeing how the teacher annotates the reading text creates awareness in reading and analyzing a text, from time to time, teachers might share their own annotated texts as well. There are many online tools that facilitate reading skills. 
Thus, the teacher might choose to implement lessons via those tools, such as Insert Learning, where students can highlight some parts of the text, insert a note, or even write a question on any web pages. For some reading sub-skills, such as identifying the main and supporting ideas, some mapping tools like MindMeister can be recommended.

Writing: Since homework concept mostly includes writing during EDE, the amount of homework should be taken into consideration. Most mid-term and final exams consist of written homework too, and this increases the workload on the shoulders of the students. Teacher collaboration on the amount of homework may solve this problem, as it was suggested for reading skills. Creating a blog may increase the motivation of the students while adding variety into the course content. The feeling of responsibility for writing a blog may give students authentic objectives and an audience. Some students might be stuck in their routines and prefer a pen and paper to write instead of a computer, tablet, or a phone; therefore teachers might opt for some alternative ways to overcome this issue. For example, a format of sending and receiving written homework can be arranged according to the context, such as writing the homework on a paper, taking a photo, and sending it to the teacher (a suitable program for that can be found). The frequency of these might be arranged within that classroom context. These needs can be assessed at the beginning of the term together with the students. One other important point is feedback because, in the absence of feedback, students tend to feel that their homework is not read, and they question whether they are on the right path or not. Thus, teachers should provide feedback for every item of homework they assign. If they cannot, some automated writing evaluation systems (e.g., Virtual Writing Tutor) might be recommended. These tools are actually helpful to remove the workload for initial checks such as spelling, punctuation, etc. With the support of such virtual tools, teachers can concentrate on a deeper analysis for cohesion, coherence, etc. Besides, students can easily see their mistakes on their own and step in to improving their writing skills. One implication of this study is plagiarism; students may copy and paste from different sources and/or cheat during online exams. One solution for decreasing, if not eliminating, such instances of academic dishonesty might be to prepare an honor code (e.g., Harvard College Honor Code) that students read and sign at the beginning of the term [72].

Listening: Higher education institutes should select a platform where the online courses can be recorded and listened to whenever and wherever the students want. This flexibility is crucial for listening skills development and is highlighted as one of the advantages of distance education settings [58]. Due to the flexibility of the courses, language teacher training programs conducted virtually in the pandemic appeal to most pre-service teachers because it gives the flexibility and comfort of home in order to manage both their education and family life. Technical problems should be handled for this skill as well. Internet connection problems might be solved by the state or the university as much as possible, as in the examples of University of York providing financial support to its students without internet access or IT equipment [73], or 6 GB assistance by mobile operators in Turkey to help university students to reach open access materials provided by YÖK [48]. The microphones of the lecturers should be checked regularly, and teachers should search for suitable podcasts or websites that give good listening practice in relation to their courses. Passively listening to their teachers might create boredom and monotony for pre-service EFL teachers, so whenever possible, there should be some space allowing them to listen to their peers or other sources. Teachers might invite one of their colleagues and implement a specific lesson together. In addition, during the COVID-19 pandemic, many organizations and institutions have begun holding free webinars. Teachers might choose a related webinar and suggest their students listen to it. Again, offering alternative webinars might attract the attention of the students and make them more motivated. In line with the course objectives, teachers might assign a task related to the webinar as well. As one of the listening sub-skills, note-taking can be stimulated and facilitated through some online tools. VideoAnt is one such tool in which the students can take notes while watching the uploaded videos. The annotations, together with the minutes taken, can be shared with the teacher in order to assess the development easily. 
Speaking: It is a well-documented fact that speaking skills are the hardest to obtain among other skills, and Turkish prospective teachers and students have been experiencing this problem for a long time. EDE has disadvantages regarding speaking, the skill most negatively affected by EDE as concluded in this study. To mitigate these disadvantages, the first thing to do would be to choose suitable platforms that allow verbal interaction. The present study demonstrated that students should be encouraged to speak and speaking-related tasks should be integrated into the online courses. This is the only skill that the participants did not have self-criticism over, which indicates that they expect some enforcement from their teachers. This situation underlines the importance of real-time lessons over recorded ones. For almost all lessons, teachers should encourage students' participation in online courses. Since the oral participation of every student is not possible for every online lesson, teachers can arrange this before each lesson by nominating students or encouraging volunteers, thus giving turns to every student until the end of the term. Second, teachers should integrate pair and group work into their courses. At this point, educators should be more creative and find ways to provide more interactive practices and actions using online platforms and in virtual environments for pre-service EFL teachers. An idea of moving from an asynchronous writing assignment (e.g., discussion forums), where students can have enough time for pre-task planning and peer feedback, to a synchronous discussion might lessen the cognitive load for speaking [40]. Also, speaking homework could be designed where students can record themselves and submit their recordings. Teachers might even assign a "speaking buddy" for practicing at regular intervals, creating stronger bonds among peers. Assigning some images and charts might be good methods for speaking practice as well. Teachers might choose a relevant image and/or chart and send those before the lesson to give students enough time to concentrate. Their ideas can be discussed during online lessons together via pair or group work. Picture prompts and charts within the Learning Network of New York Times might work well for such scenarios. For encouraging individual effort for developing speaking skills, some automated speaking evaluation systems (e.g., ELSA) might be suggested.

"Failure' is common, and success is often a result of experience and learning from past failures" [43] (p. 1). For this reason, the online courses for pre-service EFL teachers during EDE should be designed around the combination of four language skills whatever the course is. In one way or another, in virtual EFL settings, the syllabi should include tasks, assignments and activities enhancing online opportunities for individual learning and interaction with a varying percentage of each skill. Inclusion of one or two activities for each skill instead of none is thought to bring success into the EDE of pre-service EFL teachers. Among the challenges and uncertainties caused by the COVID-19 pandemic, there are some things to take into consideration. The outcome of this study might be one such item to be included in that list in order to sustain quality education (SDG 4), regardless of the circumstances.

Author Contributions: T.Ö.K. and H.T. conceived, wrote and reviewed the article together. Specifically, Data curation, T.Ö.K. and H.T.; Formal analysis, T.Ö.K. and H.T.; Methodology, T.Ö.K. and H.T.; Writing-original draft, T.Ö.K. and H.T.; Writing—review and editing, T.Ö.K. and H.T. Both authors read and agreed to the published version of the manuscript.

Funding: This research received no external funding.

Acknowledgments: We would like to express our gratitude to the pre-service EFL teachers who participated in this study and to our colleagues who helped us in distributing our questionnaire. We would like to extend our gratitude to the reviewers and the editors for their careful reading of the manuscript and their constructive remarks.

Conflicts of Interest: The authors declare no conflict of interest.

\section{Appendix A : Questionnaire}

The purpose of this study is to clarify the possible effects of the COVID-19 pandemic process on the education of pre-service EFL teachers. Please answer the questions given below sincerely considering your own experiences and thoughts regarding the courses you received during the distance 
education. The answers you give will only be utilized for this study. You are free to use English or Turkish. Thank you for your help and contributions.

My name/surname is .................

Giving consent

I hereby declare that I voluntarily participated in this study. I let the researchers use my responses as data as far as my identity remains anonymous. In addition, the researchers explained the purpose (effect of the COVID-19 pandemic on education) and nature of the study in detail and guaranteed that all information I provide for this study would be treated confidentially.

Gender: (a) Male; (b) Female

University:

Which year: (a) 1st; (b) 2nd; (c) 3rd; (d) 4th

Age:

Questions

1. Considering the distance education you received during the COVID-19 pandemic, write in detail the specific advantages/positive effects you experienced with regard to your development of following language skills $(1 \mathrm{a}, 1 \mathrm{~b}, 1 \mathrm{c}, 1 \mathrm{~d})$ :

(1a) Reading skills (advantages of distance education):

(1b) Writing skills (advantages of distance education):

(1c) Listening skills (advantages of distance education):

(1d) Speaking skills (advantages of distance education):

2. Considering the distance education procedure, which is the most positively affected skill (reading, writing, listening or speaking) by the COVID-19 pandemic?

3. Considering the distance education you received during the COVID-19 pandemic, write in detail the specific problems/challenges/negative effects you experienced with regard to your development of following language skills (3a, 3b, 3c, 3d):

(3a) Reading skills (problems with distance education):

(3b) Writing skills (problems with distance education):

(3c) Listening skills (problems with distance education):

(3d) Speaking skills (problems with distance education):

4. Considering the distance education procedure, which is the most negatively affected skill (reading, writing, listening or speaking) by the COVID-19 pandemic?

\section{References}

1. Bozkurt, A.; Sharma, R.C. Emergency remote teaching in a time of global crisis due to Corona Virus pandemic. Asian J. Distance Educ. 2020, 15, i-vi. Available online: https:/www.asianjde.org/ojs/index.php/AsianJDE/ article/view/447 (accessed on 15 June 2020).

2. Murphy, M.P. COVID-19 and emergency e learning: Consequences of the securitization of higher education for post-pandemic pedagogy. Contemp. Secur. Policy 2020, 41, 492-505. [CrossRef]

3. Peters, M.A.; Wang, H.; Ogunniran, M.O.; Huang, Y.; Green, B.; Chunga, J.O.; Quainoo, E.A.; Ren, Z.; Hollings, S.; Mou, C.; et al. China's internationalized higher education during Covid-19: Collective student autoethnography. Postdigital Sci. Educ. 2020. [CrossRef]

4. WHO (World Health Organization). Coronavirus Disease (COVID-19) Pandemic. Available online: https://www.who.int/emergencies/diseases/novel-coronavirus-2019 (accessed on 1 July 2020).

5. Naidoo, R.; Fisher, B. Reset sustainable development goals for a pandemic world. Nature 2020, 583, 198-201. [CrossRef] [PubMed] 
6. UNESCO. Guidance on Flexible Learning During Campus Closures: Ensuring Course Quality of Higher Education in Covid-19 Outbreak. Available online: https://iite.unesco.org/wp-content/uploads/2020/05/ Guidance-on-Flexible-Learning-during-Campus-Closures-in-COVID-19outbreak-SLIBNU-V1.2_0508.pdf (accessed on 1 July 2020).

7. Filho, W.L.; Brandli, L.L.; Lange Salvia, A.; Rayman-Bacchus, L.; Platje, J. COVID-19 and the UN sustainable development goals: Threat to solidarity or an opportunity? Sustainability 2020, 12, 5343. [CrossRef]

8. Iwuoha, J.C.; Jude-Iwuoha, A.U. COVID-19: Challenge to SDG and globalization. Electron. Res. J. Soc. Sci. Humanit. 2020, 2, 103-115. Available online: http://www.eresearchjournal.com/wp-content/uploads/2020/07/ 10.-Covid-19-Challenge-to-SDG-and-Globalisation-1.pdf (accessed on 11 September 2020).

9. United Nations. Quality Education: Why It Matters. Available online: https:/www.un.org/sustainabledevelopment/ wp-content/uploads/2017/02/4_Why-It-Matters-2020.pdf (accessed on 11 September 2020).

10. Sandhu, P.; de Wolf, M. The impact of COVID-19 on the undergraduate medical curriculum. Med. Educ. Online 2020, 25, 1-2. [CrossRef]

11. Carver, L.B. Supporting learners in a time of crisis. Adv. Soc. Sci. Res. J. 2020, 7, 129-136. [CrossRef]

12. UNESCO. Closing Schools Has Derailed the Lives of Kids All Over the World. Here's How We Can Help Them Keep Learning. Available online: https://en.unesco.org/news/closing-schools-has-derailed-lives-kidsall-over-world-heres-how-we-can-help-them-keep-learning (accessed on 1 July 2020).

13. Lansangan, R.V. Teaching junior high school chemistry during the COVID-19 community quarantine season: Lessons, challenges, and opportunities. KIMIKA 2020, 31, 20-37. [CrossRef]

14. Alvarez, A.J. The phenomenon of learning at a distance through emergency remote teaching amidst the pandemic crisis. Asian J. Distance Educ. 2020, 15, 127-143. Available online: http://asianjde.org/ojs/index. php/AsianJDE/article/view/453 (accessed on 15 June 2020).

15. Sobaih, A.E.E.; Hasanein, A.M.; Abu Elnasr, A.E. Responses to COVID-19 in higher education: Social media usage for sustaining formal academic communication in developing countries. Sustainability 2020, 12, 6520. [CrossRef]

16. Biasutti, M. The student experience of a collaborative e-learning university module. Comput. Educ. 2011, 57, 1865-1875. [CrossRef]

17. Biasutti, M.; Frate, S.; Concina, E. Music teachers' professional development: Assessing a three-year collaborative online course. Music Educ. Res. 2019, 21, 116-133. [CrossRef]

18. Zhou, L.; Wu, S.; Zhou, M.; Li, F. 'School's out, but class' on', The largest online education in the world today: Taking China's practical exploration during the COVID-19 epidemic prevention and control as an example. Best Evid. Chin. Edu. 2020, 4, 501-519. Available online: https://ssrn.com/abstract $=3555520$ (accessed on 1 July 2020). [CrossRef]

19. Cain, D.L.; Marrara, C.; Pitre, P.E.; Armour, S. Support services that matter: An exploration of the experiences and needs of graduate students in a distance learning environment. J. Distance Educ. Rev. De L'Educ. Distance 2003, 18, 42-56. Available online: http://ijede.ca/index.php/jde/article/view/129/101 (accessed on 15 June 2020).

20. Gacs, A.; Goertler, S.; Spasova, S. Planned online education versus crisis-prompted online language teaching: Lessons for the future. Foreign Lang. Ann. 2020, 53, 380-392. [CrossRef]

21. Williamson, B.; Eynon, R.; Potter, J. Pandemic politics, pedagogies and practices: Digital technologies and distance education during the coronavirus emergency. Learn. Media Technol. 2020, 45, 107-114. [CrossRef]

22. Hodges, C.; Moore, S.; Lockee, B.; Trust, T.; Bond, A. The difference between emergency remote teaching and online learning. Educ. Rev. 2020, 27. Available online: https://er.educause.edu/articles/2020/3/ thedifference-between-emergency-remote-teaching-and-online-learning (accessed on 1 July 2020).

23. Bozkurt, A.; Jung, I.; Xiao, J.; Vladimirschi, V.; Schuwer, R.; Egorov, G.; Lambert, S.; Al-Freih, M.; Pete, J.; Olcott, D., Jr.; et al. A global outlook to the interruption of education due to COVID-19 pandemic: Navigating in a time of uncertainty and crisis. Asian J. Distance Educ. 2020, 15, 1-126. Available online: http://www.asianjde.org/ojs/index.php/AsianJDE/article/view/462 (accessed on 15 June 2020).

24. Talidong, K.J. Implementation of emergency remote teaching (ERT) among Philippine teachers in Xi'an, China. Asian J. Distance Educ. 2020, 15, 196-201. Available online: http://www.asianjde.org/ojs/index.php/ AsianJDE/article/view/463 (accessed on 15 June 2020). 
25. Gulseven, O.; Al Harmoodi, F.; Al Falasi, M.; ALshomali, I. How the COVID-19 pandemic will affect the UN sustainable development goals? SSRN 2020, 3592933, 1-28. [CrossRef]

26. Boğaziçi Üniversitesi. Eğitim Fakültesi Yabancı Diller Eğitimi Bölümü. Available online: https://fed.boun. edu.tr/tr/yabanci-diller-egitimi-bolumu (accessed on 12 September 2020).

27. Çukurova Üniversitesi. Bilgi Paketi Ders Kataloğu (Faculty of Education, English Language Teaching). Available online: https://eobs.cu.edu.tr/ProgAmac_en.aspx?ProgID=30 (accessed on 11 September 2020).

28. YÖK (Higher Education Council). İngilizce Öğretmenliği Lisans Programı. Available online: https: //www.yok.gov.tr/Documents/Kurumsal/egitim_ogretim_dairesi/Yeni-Ogretmen-Yetistirme-LisansProgramlari/Ingilizce_Ogretmenligi_Lisans_Programi.pdf (accessed on 11 September 2020).

29. Faez, F. Developing the knowledge base of ESL and FSL teachers for K-12 programs in Canada. Can. J. Appl. Linguist. 2011, 14, 29-49. Available online: https://journals.lib.unb.ca/index.php/CJAL/article/view/19865/ 21672 (accessed on 12 September 2020).

30. Richards, J. Beyond Training: Perspectives on Language Teacher Education; Cambridge University Press: Cambridge, UK, 1998.

31. Bachman, L.F. Fundamental Considerations in Language Testing; Oxford University Press: Oxford, UK, 1990.

32. Canale, M.; Swain, M. Theoretical bases of communicative approaches to second language teaching and testing. Appl. Linguist. 1980, 1, 1-47. [CrossRef]

33. Uso-Juan, E.; Martinez-Flor, A. (Eds.) Approaches to language learning and teaching: Towards acquiring communicative competence through the four skills. In Current Trends in the Development and Teaching of the Four Language Skills; Walter de Gruyter: Berlin, Germany, 2006; Volume 29, pp. 3-25.

34. Li, D. It's always more difficult than you plan and imagine: Teachers' perceived difficulties in introducing the communicative approach in South Korea. TESOL Q. 1998, 32, 677-703. [CrossRef]

35. CASLT (Canadian Association of Second Language Teachers). Profile and Pathways Supports for Developing FSL Teachers' Pedagogical, Linguistic, and Cultural Competencies. Available online: https://www.caslt.org/ files/pd/resources/research/2009-panorama-profilepathways-en.pdf (accessed on 12 September 2020).

36. Kömür, Ş. Teaching knowledge and teacher competencies: A case study of Turkish preservice English teachers. Teach. Educ. 2010, 21, 279-296. [CrossRef]

37. Coşkun, A. Causes of the "I can understand English but I can't speak" syndrome in Turkey. J. Engl. Lang. Teach. 2016, 6, 1-12. Available online: https://files.eric.ed.gov/fulltext/EJ1131404.pdf (accessed on 15 June 2020).

38. Çağatay, S. Examining EFL students' foreign language speaking anxiety: The case at a Turkish state university. Proc. Soc. Behav. Sci. 2015, 199, 648-656. [CrossRef]

39. Coşkun, A.; Daloğlu, A. Evaluating an English language teacher education program through Peacock's model. Aust. J. Teach. Educ. 2010, 35, 24-42. [CrossRef]

40. Payne, J.S. Developing L2 productive language skills online and the strategic use of instructional tools. Foreign Lang. Ann. 2020, 53, 243-249. [CrossRef]

41. Biasutti, M. Creativity in virtual spaces: Communication modes employed during collaborative online music composition. Think. Ski. Creat. 2015, 17, 117-129. [CrossRef]

42. Coeckelbergh, M. The postdigital in pandemic times: A comment on the Covid-19 crisis and its political epistemologies. Postdigital Sci. Educ. 2020, 1-4. [CrossRef]

43. World Bank. Remote Learning and COVID-19. Available online: http://documents1.worldbank.org/curated/ en/266811584657843186/text/Rapid-Response-Briefing-Note-Remote-Learning-and-COVID-19-Outbreak. txt (accessed on 1 July 2020).

44. Biasutti, M. A comparative analysis of forums and wikis as tools for online collaborative learning. Comput. Educ. 2017, 111, 158-171. [CrossRef]

45. Gilbert, J.; Morton, S.; Rowley, J. E-learning: The student experience. Br. J. Educ. Technol. 2007, 38, 560-573. [CrossRef]

46. Seddon, F.A.; Biasutti, M. Evaluating a music e-learning resource: The participants' perspective. Comput. Educ. 2009, 53, 541-549. [CrossRef]

47. Blass, E.; Davis, A. Building on solid foundations: Establishing criteria for e-learning development. J. Furth. High. Educ. 2003, 27, 227-245. [CrossRef]

48. TEDMEM. COVID-19 Sürecinde Eğitim: Uzaktan Öğrenme, Sorunlar ve Çözüm Önerileri; Türk Eğitim Derneği Yayınları: Ankara, Turkey, 2020. 
49. Agirreazkuenaga, L. Embedding sustainable development goals in education. Teachers' perspective about education for sustainability in the Basque Autonomous Community. Sustainability 2019, 11, 1496. [CrossRef]

50. Gómez-Rey, P.; Barbera, E.; Fernández-Navarro, F. Measuring teachers and learners' perceptions of the quality of their online learning experience. Distance Educ. 2016, 37, 146-163. [CrossRef]

51. YÖK (Higher Education Council). 2019-2020 Öğretim Yili Yükseköğretim Istatistikleri. Available online: https://istatistik.yok.gov.tr/ (accessed on 1 July 2020).

52. MoNE. Bakan Selçuk, 23 Mart'ta Başlayacak Uzaktan Eğitime Ilişkin Detaylari Anlatti. Available online: https://www.meb.gov.tr/bakan-selcuk-23-martta-baslayacak-uzaktan-egitime-iliskin-detaylarianlatti/haber/20554/tr (accessed on 23 June 2020).

53. YÖK (Higher Education Council). Basın Açıklaması-Yükseköğretim Kurulu Başkanı Prof. Dr. M. A. Yekta Saraç. Available online: https://basin.yok.gov.tr/AciklamaBelgeleri/2020/04-uzaktan-egitim-ve-yksertelenmesine-iliskin.pdf (accessed on 1 July 2020).

54. YÖK (Higher Education Council). 15 Haziran 2020 Tarihi Itibariyle Üniversitelerde Akademik Takvime Dönülmesi Kararina Ilişkin Açiklama. Available online: https://basin.yok.gov.tr/AciklamaBelgeleri/2020/17akademik-takvime-donulmesine-iliskin.pdf (accessed on 1 July 2020).

55. YÖK (Higher Education Council). Yök'ten Üniversitelerdeki Sinavlarin Yüz Yüze Gerçekleştirilmeyeceğine Ilişkin Karar. Available online: https://covid19.yok.gov.tr/Sayfalar/HaberDuyuru/yok-ten-sinavlara-iliskinkarar-aspx.aspx (accessed on 1 July 2020).

56. Braun, V.; Clarke, V. Using thematic analysis in psychology. Qual. Res. Psychol. 2006, 3, 1-41. Available online: https://uwe-repository.worktribe.com/preview/1043068/thematic_analysis_revised_-_final.pdf (accessed on 11 September 2020). [CrossRef]

57. Miles, M.B.; Huberman, A.M. Qualitative Data Analysis: An Expanded Sourcebook; Sage Publications: London, UK, 1994.

58. Davis, N.L.; Gough, M.; Taylor, L.L. Online teaching: Advantages, obstacles and tools for getting it right. J. Teach. Travel Tour. 2019, 19, 256-263. [CrossRef]

59. Toquero, C.M. Emergency remote education experiment amid COVID-19 pandemic. IJERI: Int. J. Educ. Res. Innov. 2020, 15, 162-172. [CrossRef]

60. Hurd, S. Distance language learners and learner support: Beliefs, difficulties and use of strategies. Links Lett. 7 Auton. Lang. Learn. 2000, 7, 61-80. Available online: http://oro.open.ac.uk/21782/1/DLLLearnSuppLinksLetters-Hurd-2000.pdf (accessed on 15 June 2020).

61. Eren, Ö.; Öztürk, T.; Turan, C.; Bada, E. Postgraduate courses on a virtual classroom platform. Turk. Online J. Educ. Tech. 2017, 11, 585-590. Available online: http://www.tojet.net/special/2017_11_1.pdf (accessed on 11 September 2020).

62. White, C. Language Learning in Distance Education; Cambridge University Press: Cambridge, UK, 2003.

63. Wang, Y.; Sun, C. Synchronous distance education: Enhancing speaking skills via internet-based real time technology. In Proceedings of the First International Conference on Web Information Systems Engineering, Hong Kong, China, 19-21 June 2000; Zhou, X., Fong, J., Jia, X., Kambayashi, Y., Zhang, Y., Eds.; IEEE (Institute of Electrical and Electronics Engineers): Los Alamitos, CA, USA, 2000.

64. Vlachopoulos, D. COVID-19: Threat or opportunity for online education? High. Learn. Res. Commun. 2020, 10, 16-19. [CrossRef]

65. Murdoch, G. Language development provision in teacher training curricula. ELT J. 1994, 48, $253-265$. [CrossRef]

66. Lange, D.E. A blueprint for teacher development. In Second Language Teacher Education; Richards, J.C., Nunan, D., Eds.; Cambridge University Press: New York, NY, USA, 1990; pp. 245-268.

67. Hurd, S. Towards a better understanding of the dynamic role of the distance language learner: Learner perceptions of personality, motivation, roles, and approaches. Distance Educ. 2006, 27, 303-329. [CrossRef]

68. Öztürk, G.; Gürbüz, N. Speaking anxiety among Turkish EFL learners: The case at a state university. J. Lang. Linguist. Stud. 2014, 10, 1-17. Available online: http://jlls.org/index.php/jlls/article/view/178/165 (accessed on 14 June 2020).

69. Vladescu, I. Digital competences for teachers. In Proceedings of the 2nd International Conference on Lifelong Education and Leadership for ALL-ICLEL 2016, Liepaja University, Liepaja, Latvia, 21-23 July 2016; Titrek, O., Mikelsone, I., Pavitola, L., Sezen Gültekin, G., Eds.; ICLEL Conferences: Sakarya, Turkey, 2016. 
70. Tuncer, H.; Özkan, Y. Sosyal medyanın yabancı dil öğretimindeki yeri (The role of social media in foreign language teaching). In Farklı Yönleriyle Yabancı Dil Öğretimi (Foreign Language Teaching With Various Perspectives); Yılmaz, H., Yücel, E., Üğüten, S.D., Şanal, F., Eds.; Çizgi Yayınevi: Konya, Turkey, 2017; pp. 145-165.

71. Biasutti, M. A coding scheme to analyse the online asynchronous discussion forums of university students. Technol. Pedagog. Educ. 2017, 26, 601-615. [CrossRef]

72. Harvard University. The Honor Code. Available online: https://honor.fas.harvard.edu/honor-code (accessed on 14 July 2020).

73. University of York. Assistance Funding. Available online: https://www.york.ac.uk/students/finance/funding/ (accessed on 15 August 2020).

C 2020 by the authors. Licensee MDPI, Basel, Switzerland. This article is an open access article distributed under the terms and conditions of the Creative Commons Attribution (CC BY) license (http://creativecommons.org/licenses/by/4.0/). 